GA-A15628 (ADDENDUM)

\title{
MASTER
}

\section{GAS-COOLED FAST BREEDER REACTOR}

\section{QUARTERLY PROGRESS REPORT FOR THE PERIOD AUGUST 1, 1979 THROUGH OCTOBER 31, 1979}

\author{
by \\ PROJECT STAFF
}

\section{CAUTION}

Ihis-repert-eontaims potentially patentable information and should not he further disseminated without the express written consent of The Document Management Branch, BOE-Fechinicat Information Center, Oak Ridge Tenn or The Office of Paten founcel, San Francisco Operations Office, DOE San Francisco California

\author{
Prepared under \\ Contract DE-AT03-76SF71023 \\ for the San Francisco Operations Office \\ Department of Energy
}

DATE PUBLISHED: NOVEMBER 1979

\section{GENERAL ATOMIC COMPANY}




\section{DISCLAIMER}

This report was prepared as an account of work sponsored by an agency of the United States Government. Neither the United States Government nor any agency Thereof, nor any of their employees, makes any warranty, express or implied, or assumes any legal liability or responsibility for the accuracy, completeness, or usefulness of any information, apparatus, product, or process disclosed, or represents that its use would not infringe privately owned rights. Reference herein to any specific commercial product, process, or service by trade name, trademark, manufacturer, or otherwise does not necessarily constitute or imply its endorsement, recommendation, or favoring by the United States Government or any agency thereof. The views and opinions of authors expressed herein do not necessarily state or reflect those of the United States Government or any agency thereof. 


\section{DISCLAIMER}

Portions of this document may be illegible in electronic image products. Images are produced from the best available original document. 


\section{NOTICE}

This report was prepared as an account of work sponsored by the United States Government. Neither the United States nor the Department of Energy, nor any of their employees, nor any of their contractors, subcontractors, or their employees, makes any warranty, express or implied, or assumes any legal liability or responsibility for the accuracy, completeness or usefulness of any information, apparatus, product or process disclosed, or represents that its use would not infringe privately owned rights. 
GA-A15628 (ADDENDUM)

\title{
GAS-COOLED FAST BREEDER REACTOR
}

\author{
QUARTERLY PROGRESS REPORT FOR THE PERIOD \\ AUGUST 1, 1979 THROUGH OCTOBER 31, 1979
}

\author{
by \\ PROJECT STAFF
}

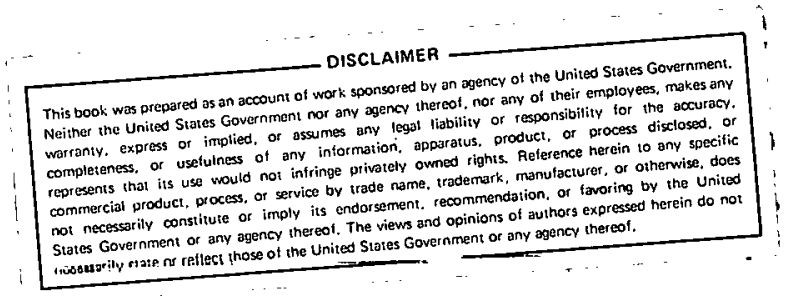

\begin{abstract}
Prepared under
Contract DE-AT03-76SF71023

for the San Francisco Operations Office

Department of Energy
\end{abstract}

\author{
GENERAL ATOMIC PROJECT 6114 \\ DATE PUBLISHED: NOVEMBER 1979
}

\section{GENERAL ATOMIC COMPANY}


THIS PAGE

\section{WAS INTENTIONALLY \\ LEFT BLANK}


CONTENTS

REFUELING UNDER PRESSURIZED CONDITIONS . . . . . . . . . . . . 1

REACTOR CORE . . . . . . . . . . . . . . . . . . . . . . 11

ASSEMBLY THERMAL-HYDRAULIC TESTS . . . . . . . . . . . . . . . 22

CORE ASSEMBLY FABRICATION DEVELOPMENT . . . . . . . . . . . . . . 24

NEW SHIELDING CONCEPTS . . . . . . . . . . . . . . . . . 28

SHIELDING PHYSICS DESIGN AND ANALYSIS ............... 33

KEHERENCES . . . . . . . . . . . . . . . . . . . . . 4 41

\section{FIGURES}

1. Reactor isulation valve ................. . . . 2 2

2. Rotating shield refueling system for upflow design . . . . . . 4

3. Circulator removal concept . . . . . . . . . . . . . . 5

4. Gate valve for circulator removal . . . . . . . . . . . 9 9

5. General configuration of two-loop upflow core . . . . . . . . 16

6. General configuration of commercial upflow core . . . . . . . 17

7. Cross section of fuel, blanket, control, and radial shield assemblies . . . . . . . . . . . . . 18

8. General arrangement of fuel assembly . . . . . . . . . . . 19

9. General arrangement of control assembly . . . . . . . . . . 20

10. General arrangement of blanket assembly . . . . . . . . . . 21

11. Mixing vane . . . . . . . . . . . . . . . . . . . 23

12. One of five SMART grid spacers fabricated from 316 stainless

13. One of two mandrel drawn ducts of $20 \%$ cold-worked stainless steel for SMART . . . . . . . . . . . . . . 27

14. Plan view of herringbone concept for upper and lower plenum shielding . . . . . . . . . . . . . . . . . . . . 29

15. Plan view of chevron concept for upper and lower plenum shielding . . . . . . . . . . . . . . . . 30

16. Plan view of crescent concept for upper and lower plenum shielding. . . . . . . . . . . . . . . . . . 
17. Plan view of offset hole concept for upper and lower plenum shielding.......................

18. Plan view and vertical section of core and radial shielding for two-loop upflow GCFR. . . . . . . . . . . . . . .

19. Proposed upper plenum shielding with flow through vertical section for upflow GCFR . . . . . . . . . . . . . . . .

20. Proposed lower plenum shielding with flow through vertical section for two-loop upflow GCFR ... . . . . . . . . . . .

21. Proposed upper plenum shielding with circular flow in horizontal plane for two-loop upflow GCFR. . . . . . . . . 37

22. Proposed lower plenum shielding with circular flow in horizontal plane for two-loop upflow GCFR. . . ........

23. Proposed lower plenum shielding with circular flow for two-loop upflow GCFR (section above level of grid plate).....

\section{TABLE}

1. GCFR core mechanical design characteristics ........... 
REFUELLING UNDER PRESSURIZED CONDITIONS

Pressurized coolant capability during refueling and maintenance is being considered as a means of enhancing core cooling by natural circulation. Two cases were considered. Case 1, refueling with the reactor at subatmospheric pressure, permits a situation in which a refueling penetration closure can be unbolted and removed and an isolation valve installed "hands-on." The control rod drive can then be removed by a cask. The isolation valve is maintained in a closed position until the cask containing the fuel handling machine is in place. At that time the valve is reopened and the fuel handling machine lowered into place through the valve. Adequate shielding and prevention of excessive air ingress is provided by the equipment occupying the penetration. The only provision necessary for permiting pressurization to above atmospheric pressure is that the isolation valve and its attachment and sealing to a penetration be designed for the required pressure. In the present fuel handling concept, the fuel handling machine is mainly housed in the penetration and partly in the isolation valve body, but below the valve. It is therefore only necessary to ensure that the fuel transfer cask grapple (and a core assembly, if attached) is retracted into the fuel transfer cask and the valve closed for the syștem to be secured for repressurization. The fuel transfer cask bistem forms the duct to provide forced cooling to the element during the time it is handled. Figure 1 shows a typical isolation valve which is suitable for these conditions. No problems are anticipated in performing these operations within the stipulated time frame.

Case 2, performing the entire refueling sequence with the reactor pressurized at $1.034 \times 10^{6} \mathrm{MPa}$ requires not only that all related equipment be designed for that pressure, but also that a return to atmospheric pressure be made at some point in the sequence prior to discharge of a spent assembly into the storage pool. The converse holds true, of course, for replacement core assemblies. No particular problem is involved other than that the depressurization/repressurization will add somewhat to the overall refueling time. 


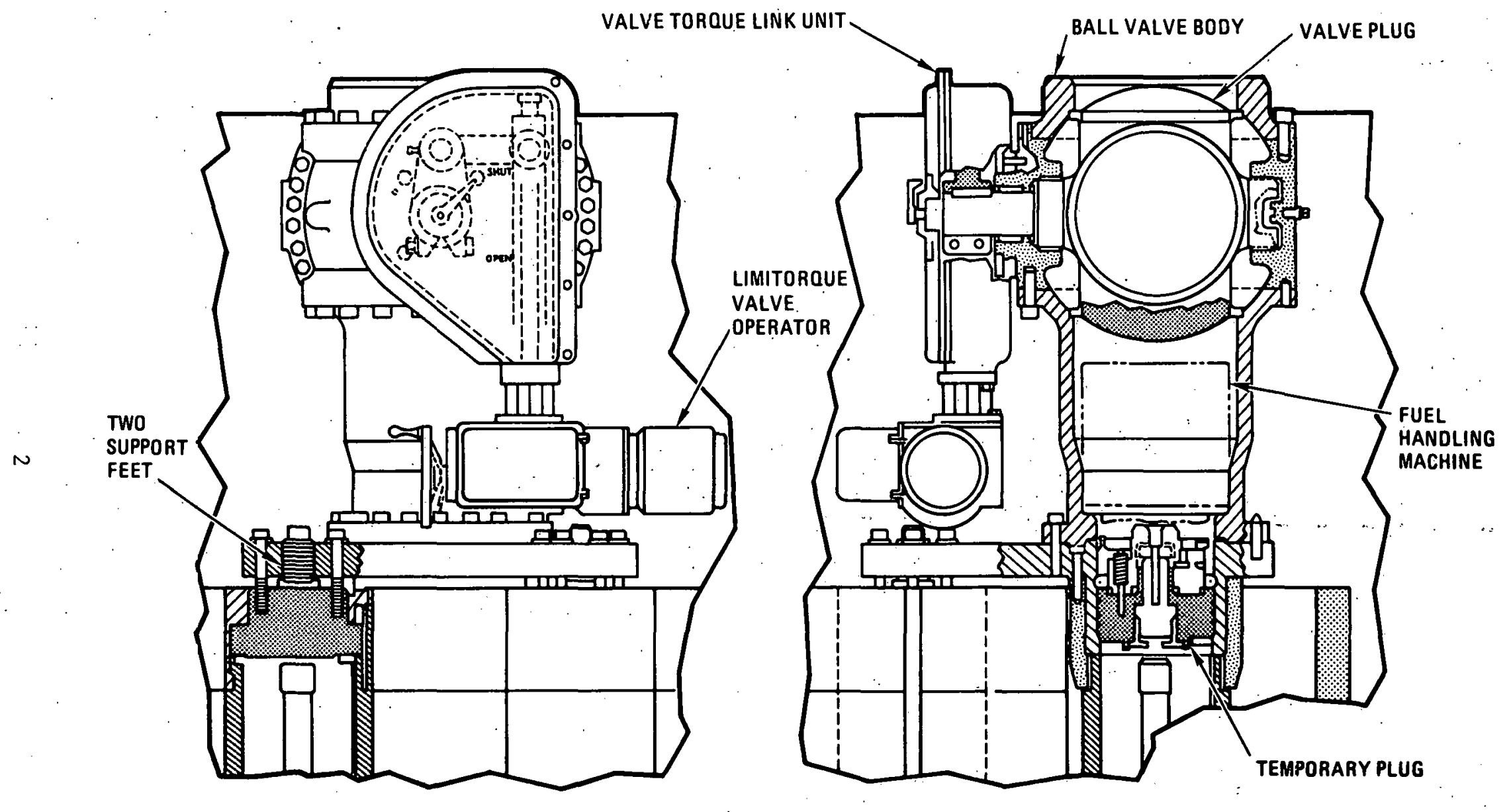

Fig. 1. Reactor isolation valve 
The main problem appears to be in opening up a refueling penetration and installing an isolation valve. One solution which has been tried in several U.K. reactors is to have a special plug located below the primary closure of the penetration similar to that shown in the right-hand view of Fig. 1. With such a device in place, the primary closure can be manually removed and the 1solation valve manually installed. A special machine is then mounted on the isolation valve, purged, back-filled with helium, and pressure equalized. The machine can subsequently unlock a control rod from the drive line and remove and store the special plug. The isolation valve is then closed and the appropriate cask installed.

Figure 2 shows an alternative to the plug approach, i.e., a rotating floor comprising of two eccentric assemblies which replace the missile shields usually located above the refueling penetrations. The interspace is pressurized to $1.03 \times 10^{6} \mathrm{MPa}$ for refueling. One of three isolation valves installed on the floor can be moved into position over the desired penetration. The machine then unlocks the control rod and removes the penetration. The special plug is not required in this case. This alternative gives an anticipated savings in refueling time with some capital cost penalty.

The procedures for removing a circulator for cases 1 and 2 are similar. Case 1 permits "hands-on" removal of all circulator flange bolts, and case 2 requires that the shipping cask be designed for $1.034 \times 10^{6} \mathrm{MPa}$ instead of a lower pressure. In both cases the valve must be designed for $1.034 \times 10^{6} \mathrm{MPa}$.

Figure 3 shows an arrangement consisting of a cask, a vertical gate valve, and an adapter housing and flange bolted to the circulator primary closure. The entire assembly is mounted on a transporter and has various adjustment points to ensure proper alignment with the circulator. After removal of the drive motor, the handling equipment is moved into place with the gate valve open and manually bolted to the primary closure to form a gas-tight seal. A limited number of circulator retaining bolts can also be manually removed at this time. A rail-supported carriage is attached to 


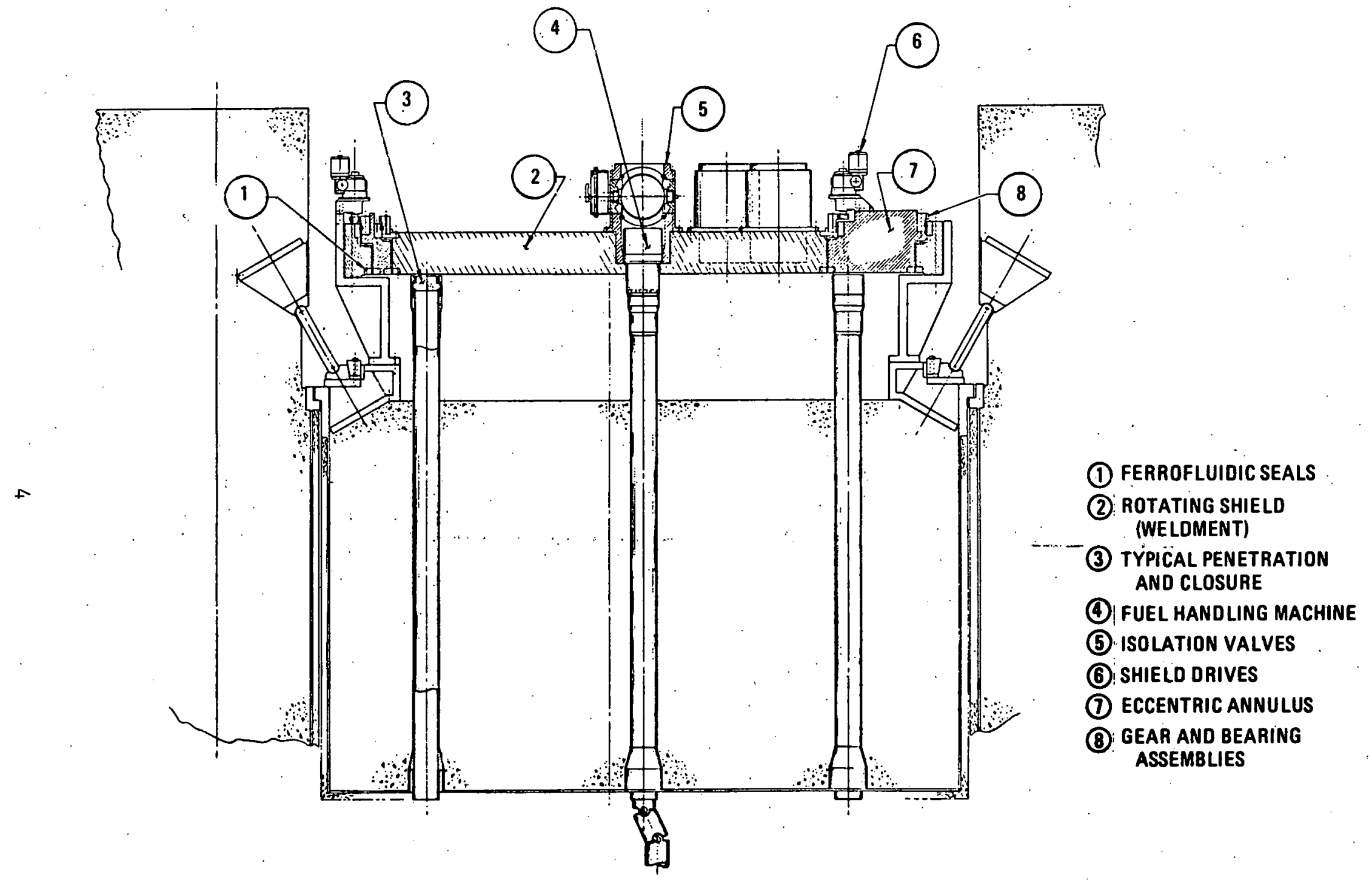

Fig. 2. Rotating shield refueling system for upflow design 


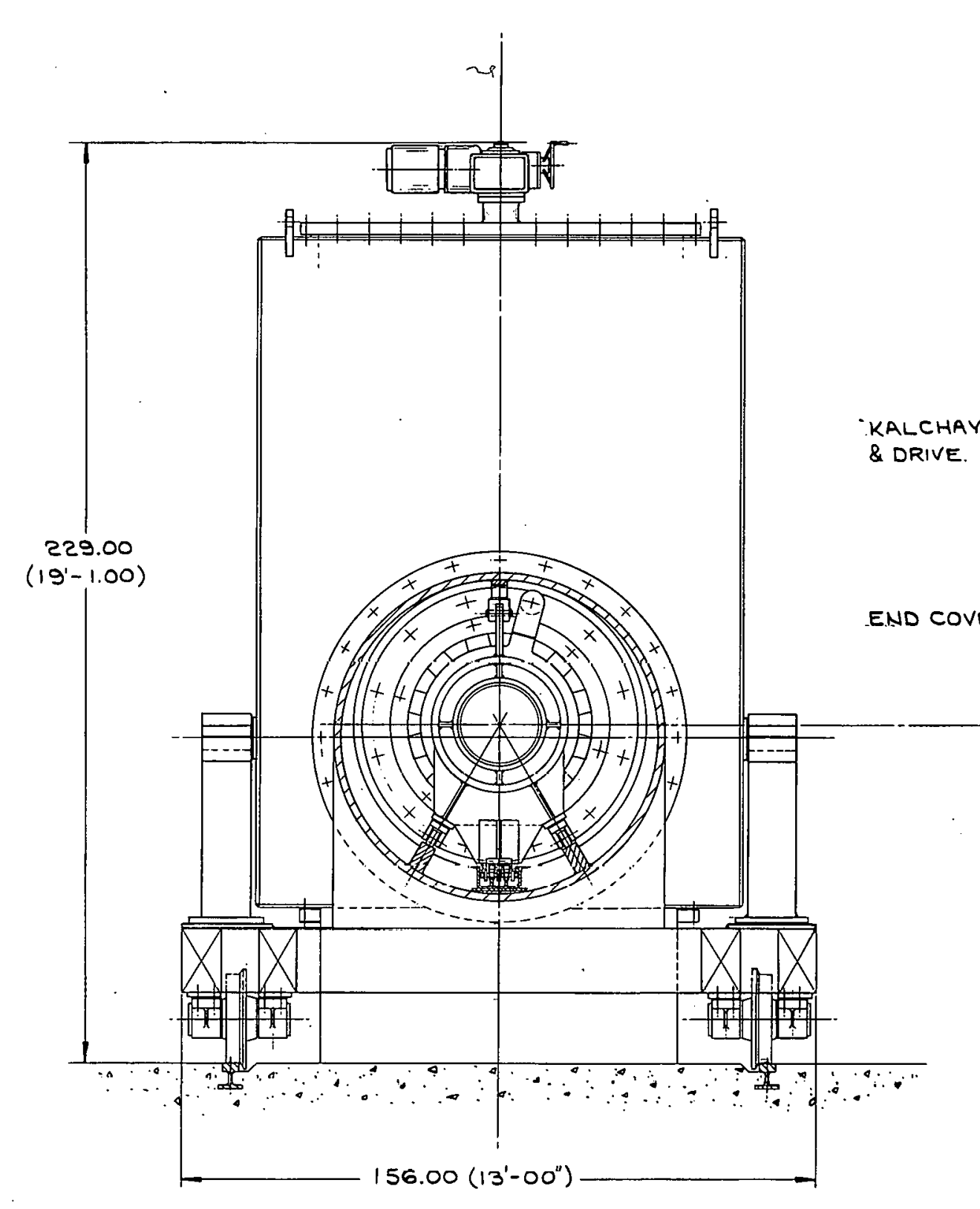

SECTION A - A

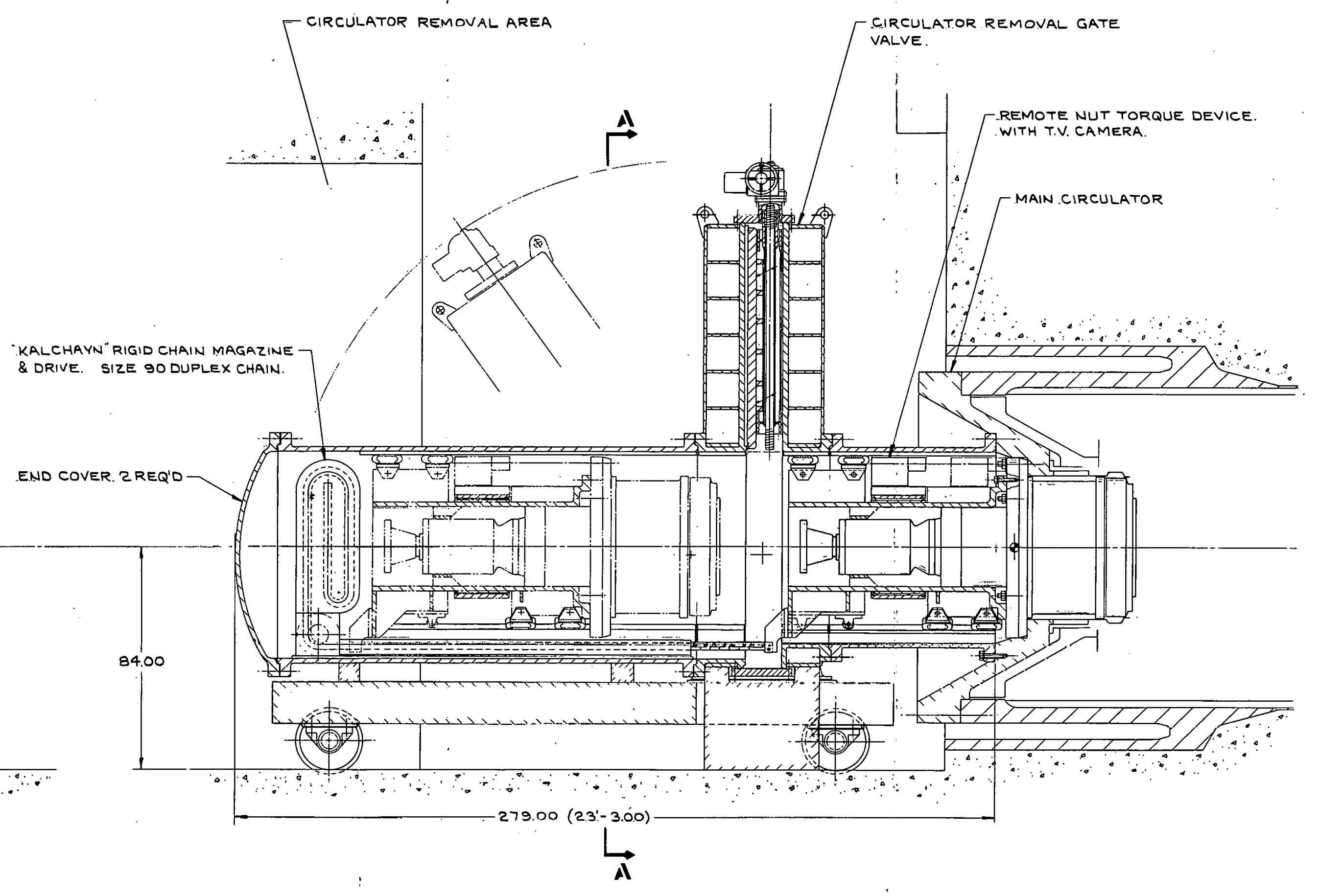

Fig. 3. Circulator removal concept 
THIS PAGE

\section{WAS INTENTIONALLY \\ LEFT BLANK}


the circulator. This carriage is pulled back and forth by a drive mechanism located on the cask. The handling equipment is purged, back-filled with helium, and pressurized to $1.034 \times 10^{6} \mathrm{MPa}$. A bolt-torquing device which is integral with the housing and gate assembly is remotely actuated to remove the remaining circulator bolts (various jacking and load-sensing devices are activated to support the circulator load and maintain proper alignment). The circulator is withdrawn into the cask, the gate valve closed, and the cask purged to an air or helium environment at atmospheric pressure. The cask is finally unbolted from the valve assembly and an end cover installed.

No special problems are anticipated in the design and construction of acceptable equipment. Figure 4 shows a typical 198.12-cm valve design which consists of a power-driven gate with a mechanically energized sealing arrangement. 
THIS PAGE

\section{WAS INTENTIONALLY \\ LEFT BLANK}




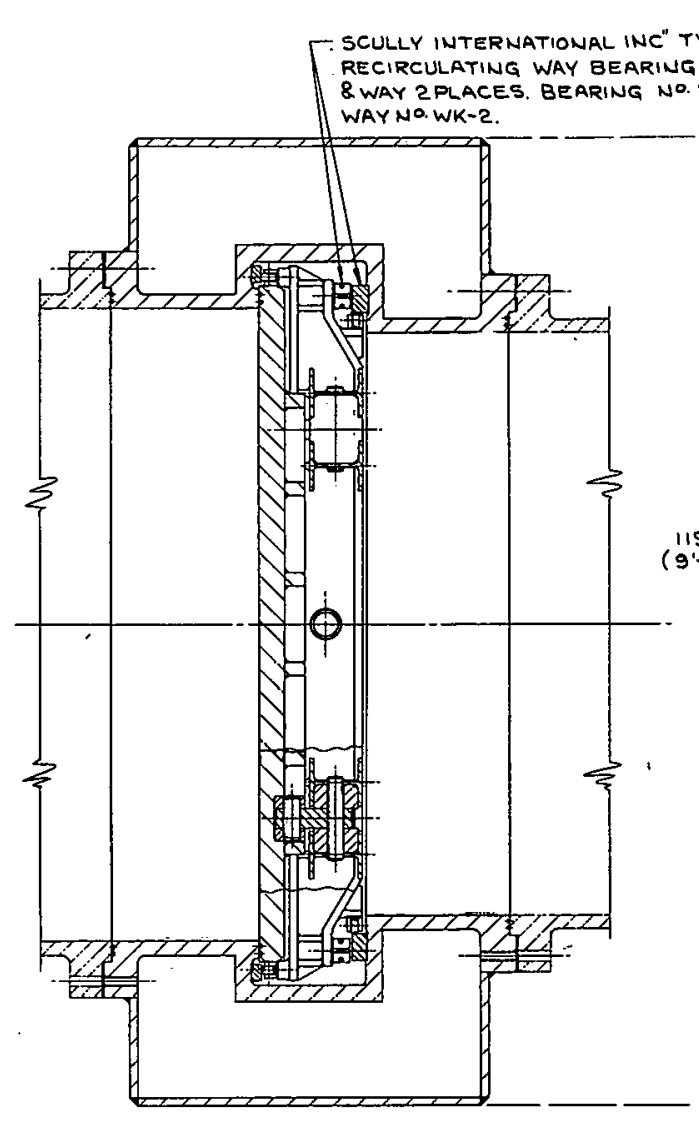

SECTION $\mathbf{1 3}-\mathbf{B}$

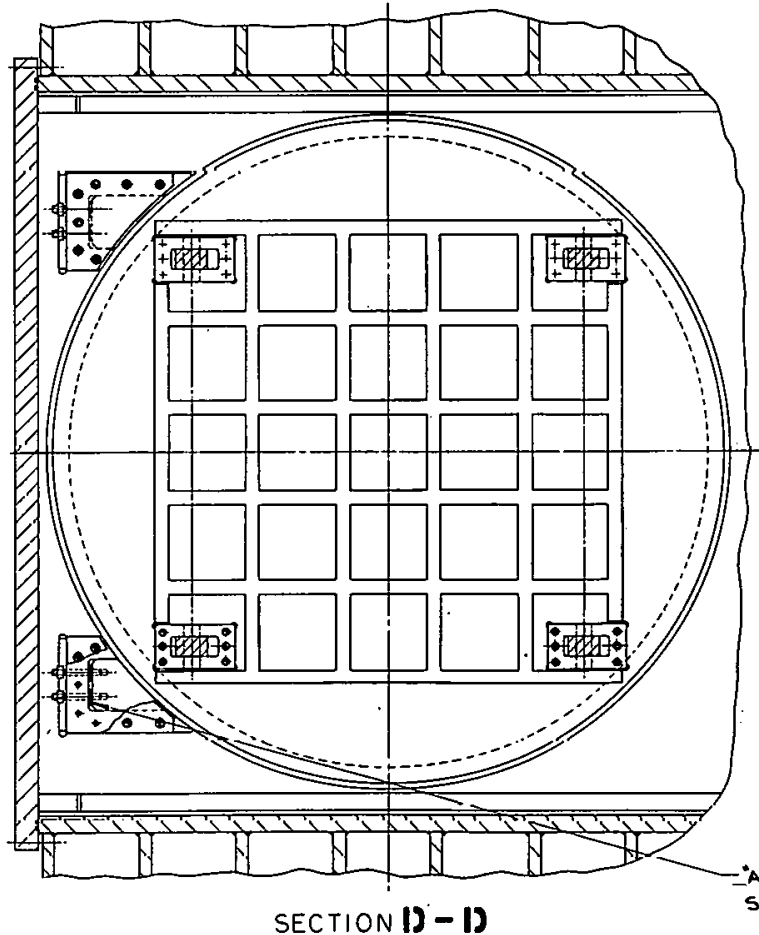

SECTION IJ - D

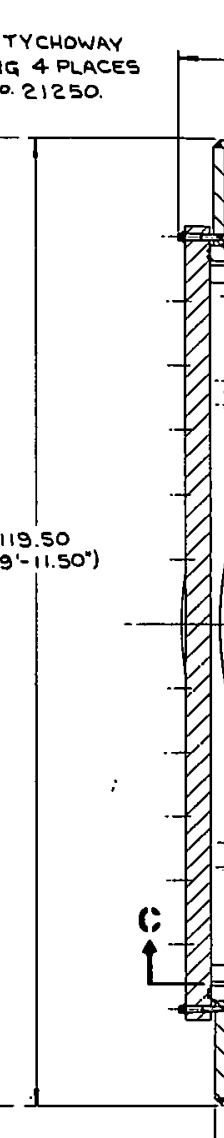

$\Gamma^{13}$

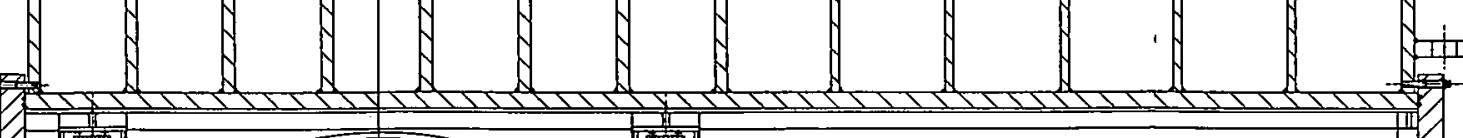

-

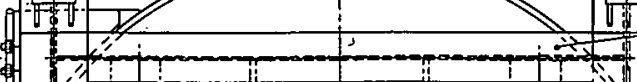

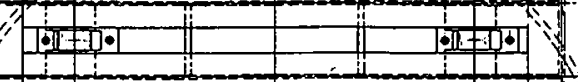
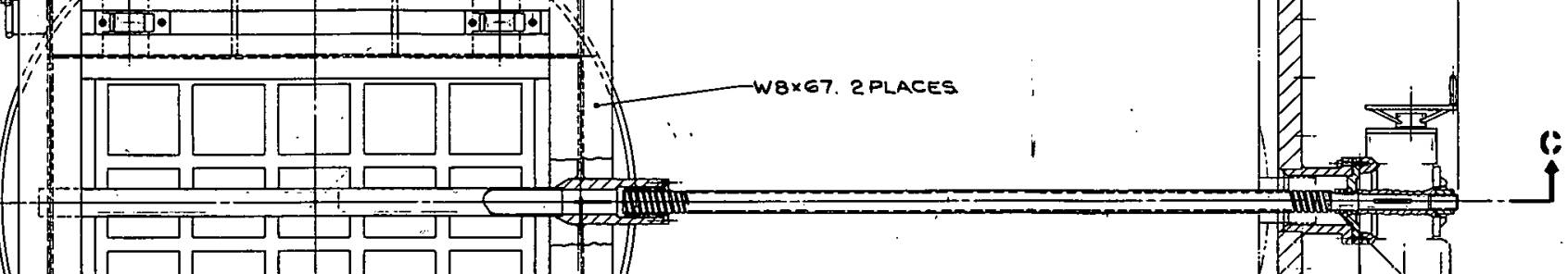

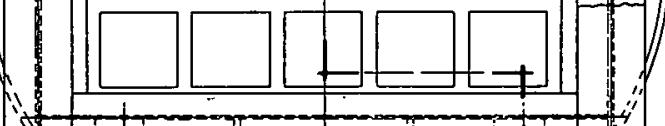

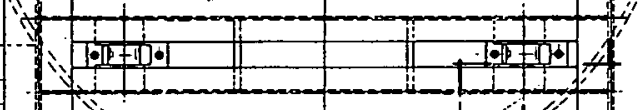

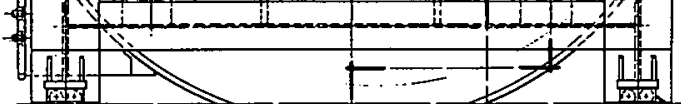

1

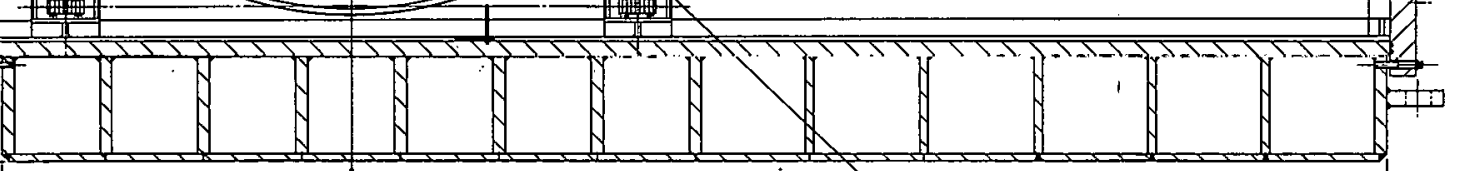

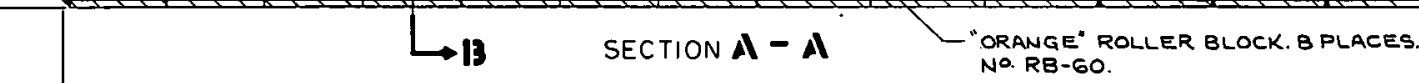
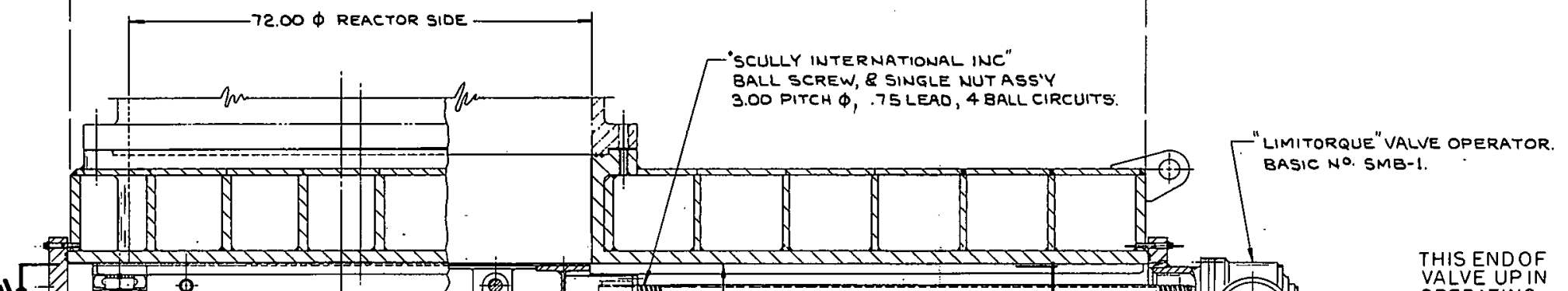

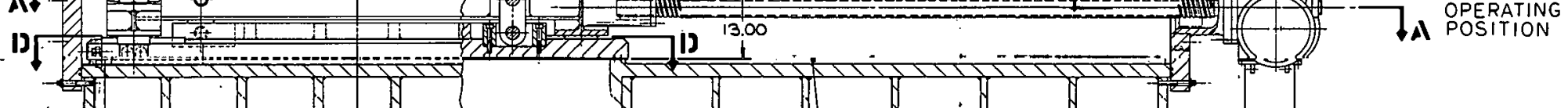

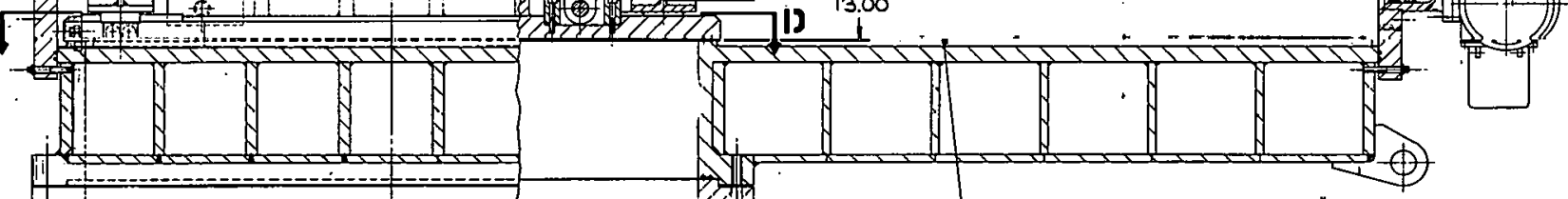

SCULLY INTERNATIONAL INCC
WAY 2 PLACES NO. WK-I.

Fig. 4. Gate valve for circulator removal 
Blank

10 
Tentative revisions were made to the reactor core for the two-loop demonstration and lead commercial plants. The proposed revisions reflect the following:

1. Expansion of the core design data to include the control, blanket, and reflector/shield assemblies.

2. Use of a dedicated configuration for the control assembly (without peripheral fuel rods).

3. The use of reduced duct wall thicknesses and interassembly gaps with corresponding decreases in fuel assembly pitches.

4. Removal of the guide tube from the fuel assembly center position. The number of fuel rods per assembly increased from 264 to 265 .

5. Introduction of $\mathrm{D} 9$ for the cladding and duct material in the demonstration plant and D9 cladding and HT9 ducts in the commercial plant.

Table 1 and Figs. 5 through 10 present the revised design information and configuration arrangements. 
TABLE 1

GCFR CORE MECHANICAL DESIGN CHARACTERISTICS

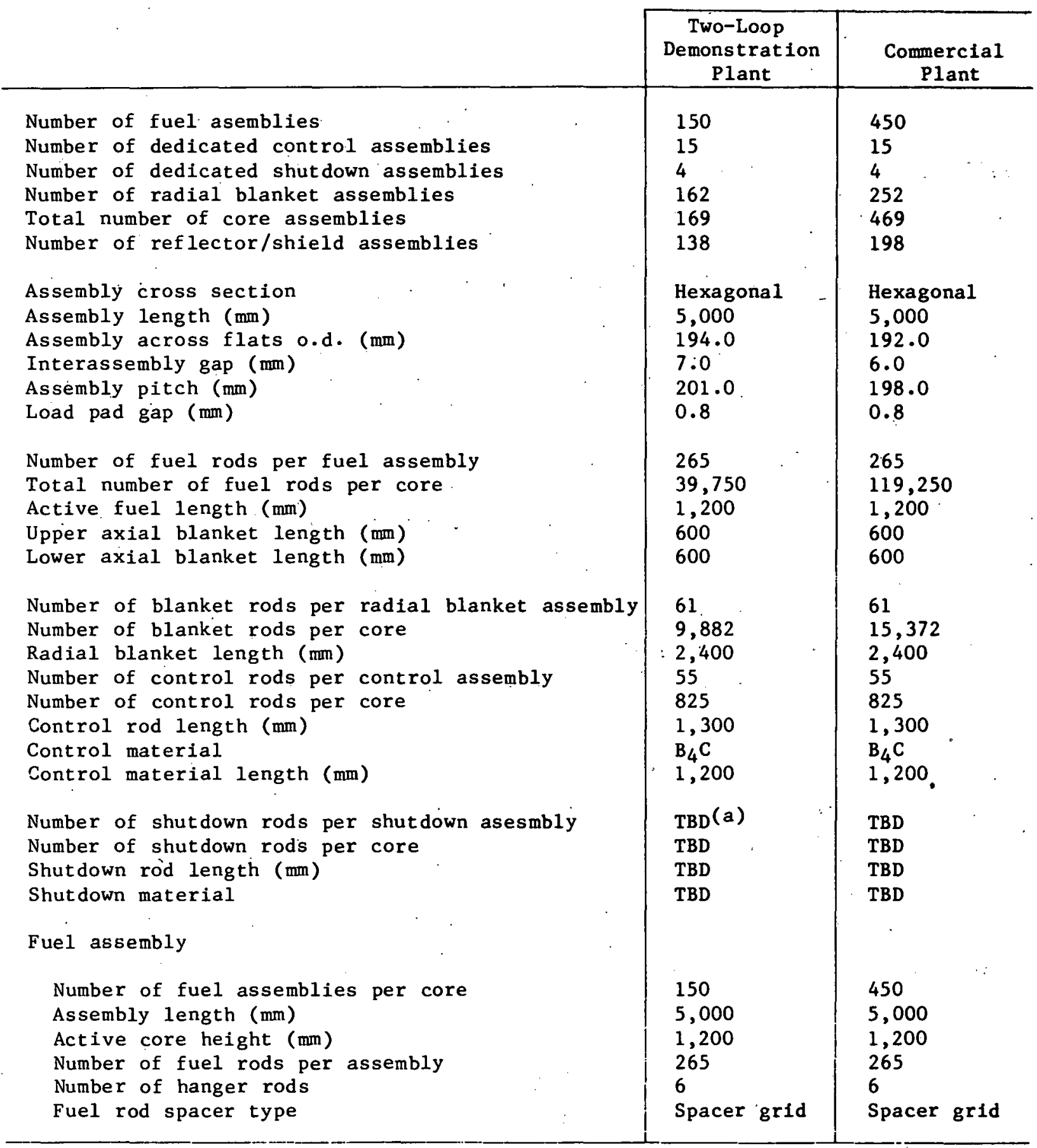

(a) $\mathrm{TBD}=$ to be determined. 


\begin{tabular}{|c|c|c|}
\hline & $\begin{array}{c}\text { Two-Loop } \\
\text { Demonstration } \\
\text { - Plant }\end{array}$ & $\begin{array}{c}\text { Commercial } \\
\text { Plant }\end{array}$ \\
\hline $\begin{array}{l}\text { Number of spacer grids } \\
\text { Duct material } \\
\text { Duct across flats } 1 . d . \text { (mm) } \\
\text { Duct across flats o.d. (mm) } \\
\text { Duct wall thickness (mm) } \\
\text { Fuel rod pitch (mm) } \\
\text { Rod-to-rod gap (mm) } \\
\text { Rod-to-duct gap (mm) } \\
\text { Rod-to-duct gap (\% of rod-to-rod gap) } \\
\text { Fuel assembly pitch (mm) }\end{array}$ & $\begin{array}{l}12 \\
\text { D } 9 \\
186.0 \\
1.94 .0 \\
4.0 \\
11.1 \\
3.1 \\
2.48 \\
80 \\
201.0\end{array}$ & $\begin{array}{l}12 \\
\text { HT-9 } \\
186.0 \\
192.0 \\
3.0 \\
11.1 \\
3.1 \\
2.48 \\
80 \\
198.0\end{array}$ \\
\hline \multicolumn{3}{|l|}{ Fuel rod } \\
\hline $\begin{array}{l}\text { Length (mm) } \\
\text { O.D. (mm) } \\
\text { Outside root diameter (mm) } \\
\text { Average volumetric diameter in rough }\end{array}$ & $\begin{array}{l}2870 \\
8.00 \\
7.74 \\
7.815\end{array}$ & $\begin{array}{l}2870 \\
8.00 \\
7.74 \\
7.815\end{array}$ \\
\hline $\begin{array}{l}\text { I.D. (mm) } \\
\text { Cladding root thickness (mm) } \\
\text { Cladding material } \\
\text { Fuel and axial blanket pellet o.d. (mm) } \\
\text { Fuel and axial blanket pellet-to-cladding } \\
\quad \text { diametral gap (mm) }\end{array}$ & $\begin{array}{l}6.98 \\
0.38 \\
D 9 \\
6.84 \\
0.14\end{array}$ & $\begin{array}{l}6.98 \\
0.38 \\
D 9 \\
6.84 \\
0.14\end{array}$ \\
\hline $\begin{array}{l}\text { Fuel column length ( } \mathrm{mm}) \\
\text { Fuel material } \\
\text { Fuel material planar smear density (\% of } \\
\text { theoretical density) }\end{array}$ & $\begin{array}{l}1,200 \\
(\mathrm{U}, \mathrm{Pu}) \mathrm{O}_{2} \\
85.5\end{array}$ & $\begin{array}{l}1,200 \\
(\mathrm{U}, \mathrm{Pu}) \mathrm{O}_{2} \\
85.5\end{array}$ \\
\hline $\begin{array}{l}\text { Axial blanket column length (each) (mm) } \\
\text { Axial blanket material } \\
\text { Axial blanket material planar smear density } \\
\quad \text { (\% of theoretical density) }\end{array}$ & $\begin{array}{l}600 \\
\text { Depleted } \mathrm{UO}_{2} \\
90.0\end{array}$ & $\begin{array}{l}600 \\
\text { Depleted } \mathrm{UO}_{2} \\
90.0\end{array}$ \\
\hline \multicolumn{3}{|l|}{ Roughness geonetry } \\
\hline $\begin{array}{l}\text { Rib shape } \\
\text { Rib height }(\mathrm{mm}) \\
\text { Rib width }(\mathrm{mm}) \\
\text { Rib pitch }(\mathrm{mm}) \\
\text { Length of roughening }\end{array}$ & $\begin{array}{l}\text { Trapezoidal } \\
0.13 \\
0.45 \\
1.56 \\
1,220\end{array}$ & $\begin{array}{l}\text { Trapezoidal } \\
0.13 \\
0.45 \\
1.56 \\
1,220\end{array}$ \\
\hline \multicolumn{3}{|l|}{ Control assembly } \\
\hline $\begin{array}{l}\text { Number of dedicated control assemblies per core } \\
\text { Assembiy length }(\mathrm{mm})\end{array}$ & $\begin{array}{l}15 \\
5,000\end{array}$ & $\begin{array}{l}15 \\
5,000\end{array}$ \\
\hline
\end{tabular}




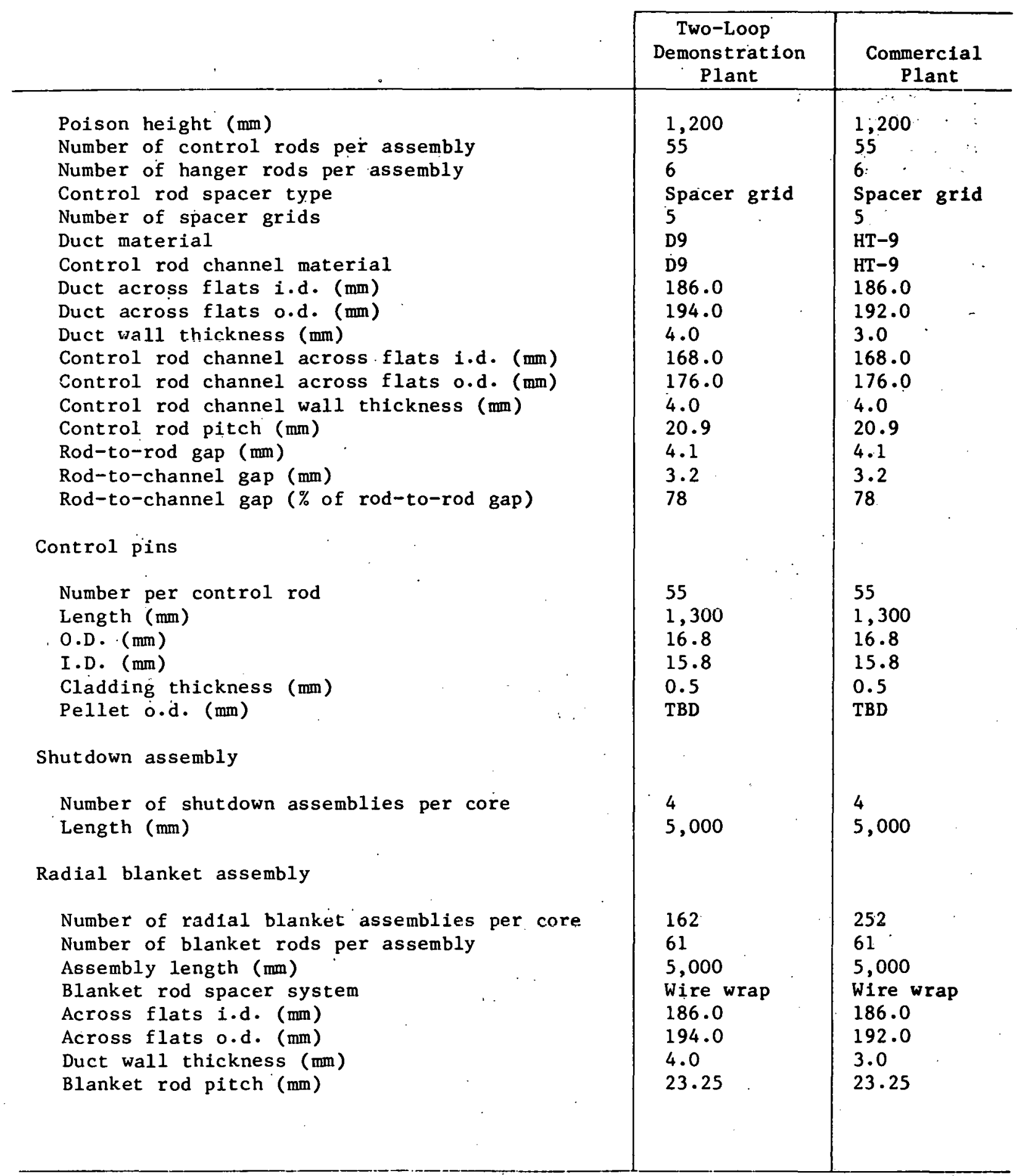




\begin{tabular}{|c|c|c|}
\hline & $\begin{array}{c}\text { Two-Loop } \\
\text { Demonstration } \\
\text { Plant }\end{array}$ & $\begin{array}{c}\text { Commercial } \\
\text { Plant }\end{array}$ \\
\hline \multicolumn{3}{|l|}{ Blanket rod } \\
\hline $\begin{array}{l}\text { Blanket material axial length (mm) } \\
\text { O.D. (mm) } \\
\text { Cladding material } \\
\text { I.D. (mm) } \\
\text { Wire wrap diameter (mm) } \\
\text { Wire wrap pitch (mm) } \\
\text { Blanket material } \\
\text { Blanket material smear density (\% of } \\
\text { theoretical density) } \\
\text { Blanket pellet o.d. (mm) } \\
\text { Reflector/shield assembly }\end{array}$ & $\begin{array}{l}2,400 \\
21.70 \\
\mathrm{D} 9 \\
20.70 \\
1.45 \\
300.0 \\
\text { Depleted } \mathrm{UO}_{2} \\
90.0 \\
20.55\end{array}$ & $\begin{array}{l}2,400 \\
21.70 \\
\mathrm{D} 9 \\
20.70 \\
1.45 \\
300.0 \\
\text { Depleted } \mathrm{UO}_{2} \\
90.0 \\
20.55\end{array}$ \\
\hline $\begin{array}{l}\text { Number of reflector/shield assemblies } \\
\text { Assembly length (mm) } \\
\text { Number of shielding rods per assembly } \\
\text { Shielding rod spacer type } \\
\text { Across flats i.d. (mm) } \\
\text { Across flats o.d. (mm) } \\
\text { Duct wall thickness (mm) } \\
\text { Shielding rod pitch (mm) }\end{array}$ & $\begin{array}{l}138 \\
5,000 \\
19 \\
\text { Wire wrap } \\
186.0 \\
194.0 \\
4.0 \\
41.35\end{array}$ & $\begin{array}{l}198 \\
5,000 \\
19 \\
\text { Wire wrap } \\
186.0 \\
192.0 \\
3.0 \\
41.35\end{array}$ \\
\hline \multicolumn{3}{|l|}{ Shielding rod } \\
\hline $\begin{array}{l}\text { Shielding material axial length (mm) } \\
\text { O.D. (mm) } \\
\text { I.D. (mm) } \\
\text { Wire wrap diameter (mm) } \\
\text { Wire wrap pitch (mm) } \\
\text { Shielding material } \\
\text { Shielding pellet o.d. (mm) } \\
\text { Cladding material }\end{array}$ & $\begin{array}{l}\text { TBD } \\
40.1 \\
39.1 \\
1.20 \\
\text { TBD } \\
\text { Boronated } \\
\text { graphite } \\
39.0 \\
\text { D9 }\end{array}$ & $\begin{array}{l}\text { TBD } \\
40.1 \\
39.1 \\
1.20 \\
\text { TBD } \\
\text { Boronated } \\
\text { graphite } \\
39.0 \\
\text { D9 }\end{array}$ \\
\hline
\end{tabular}




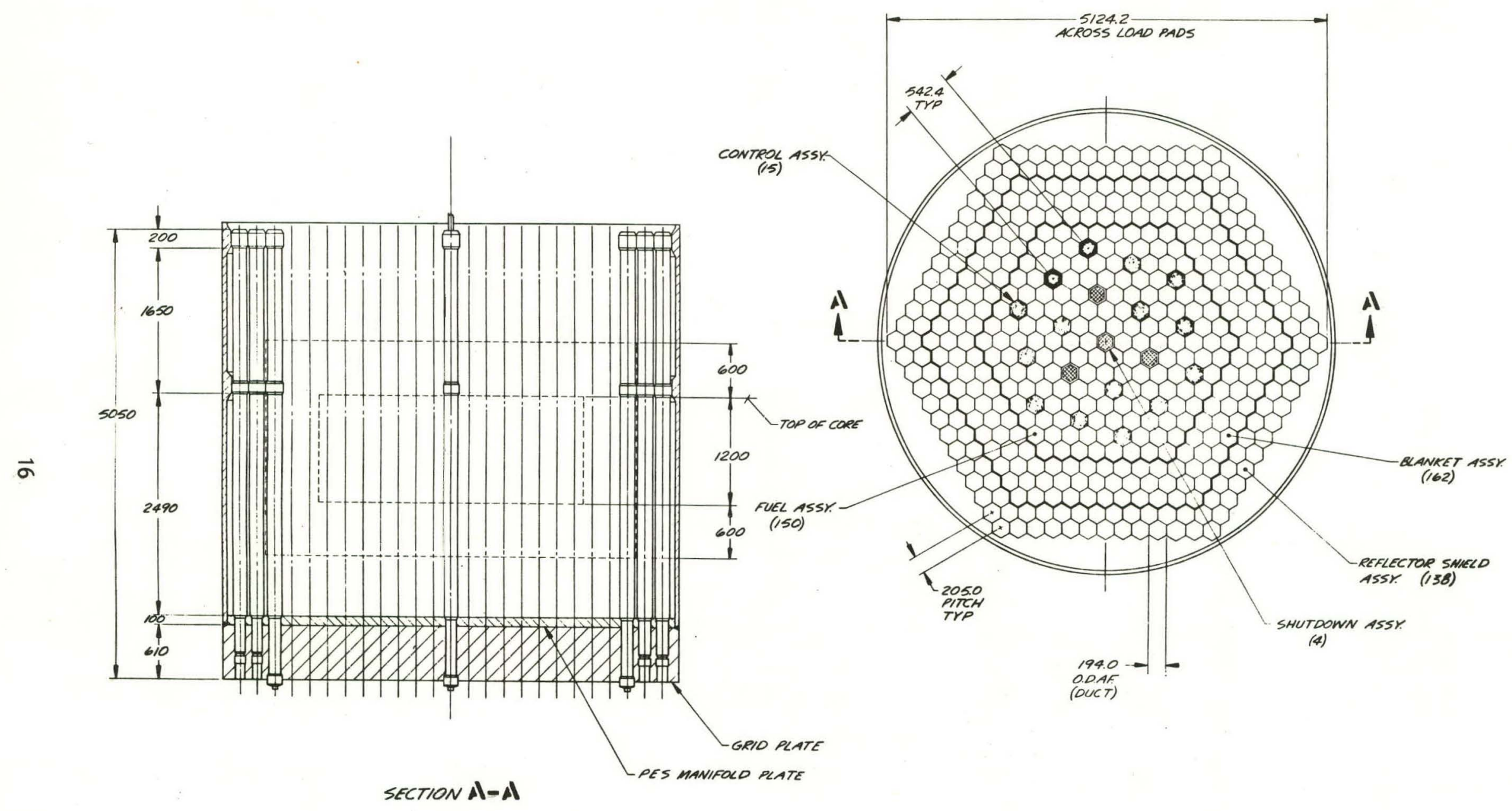

Fig. 5. General configuration of two-loop upflow core 


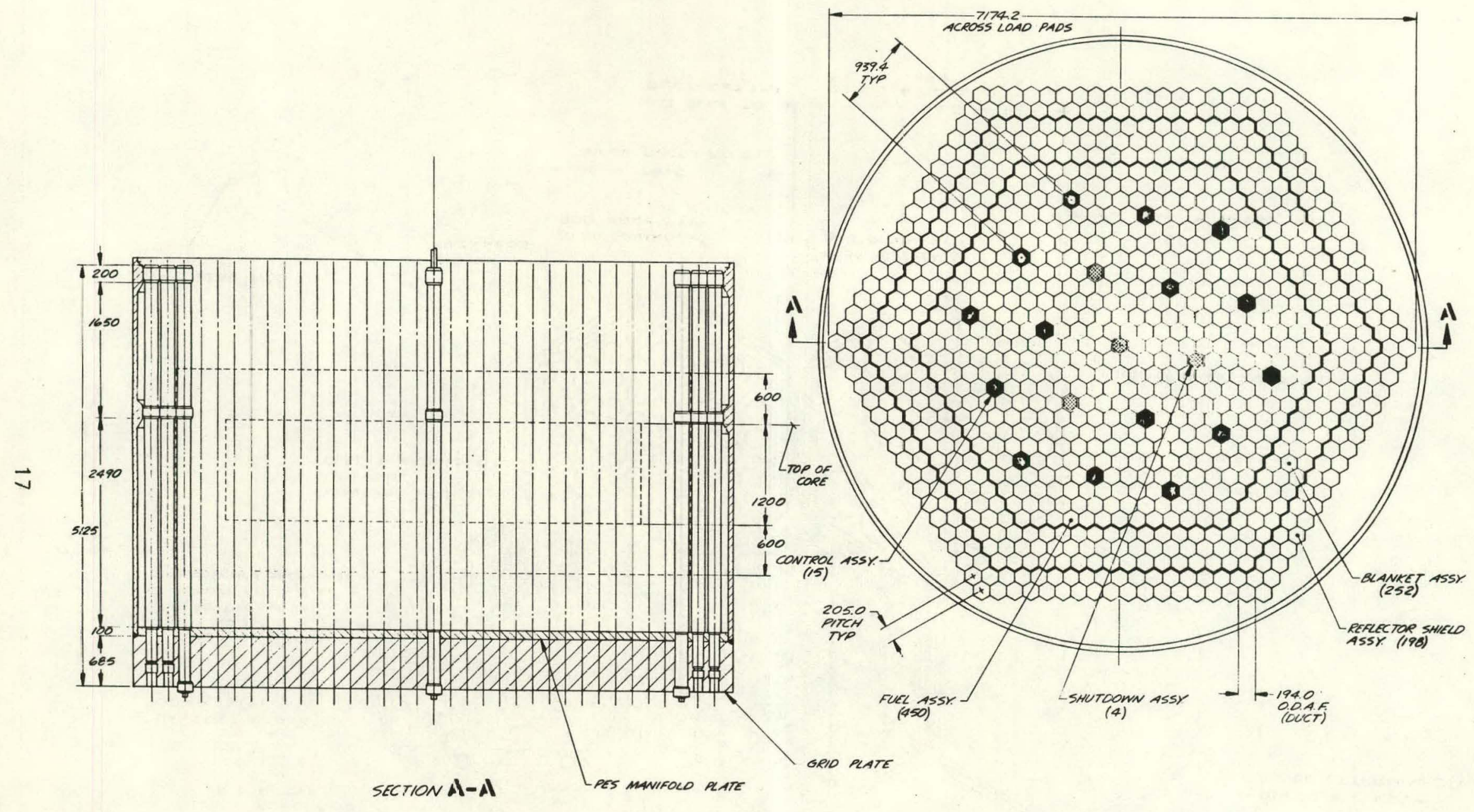

Fig. 6. General configuration of commercial upflow core 


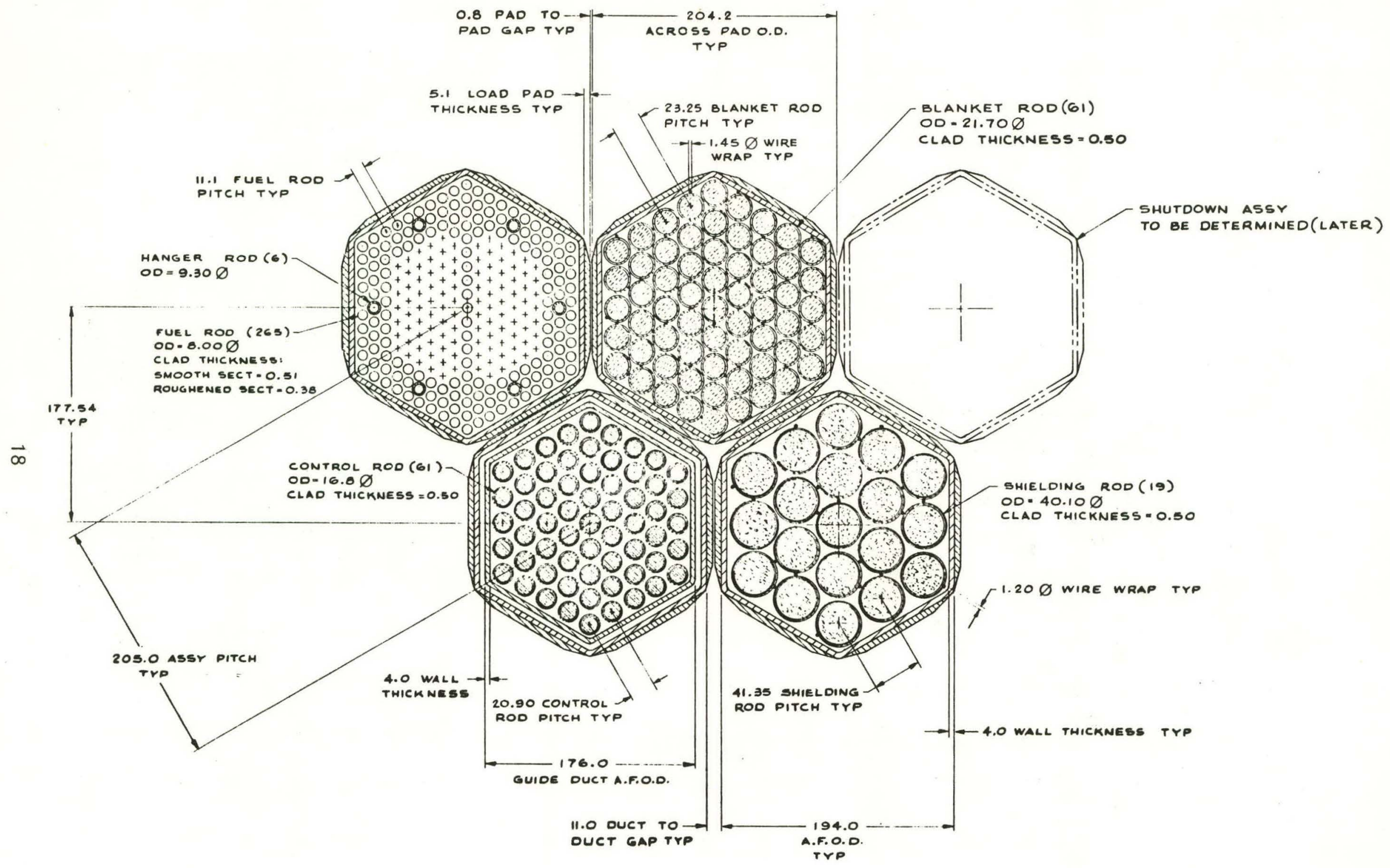

Fig. 7. Cross section of fuel, blanket, control, and radial shield assemblies 

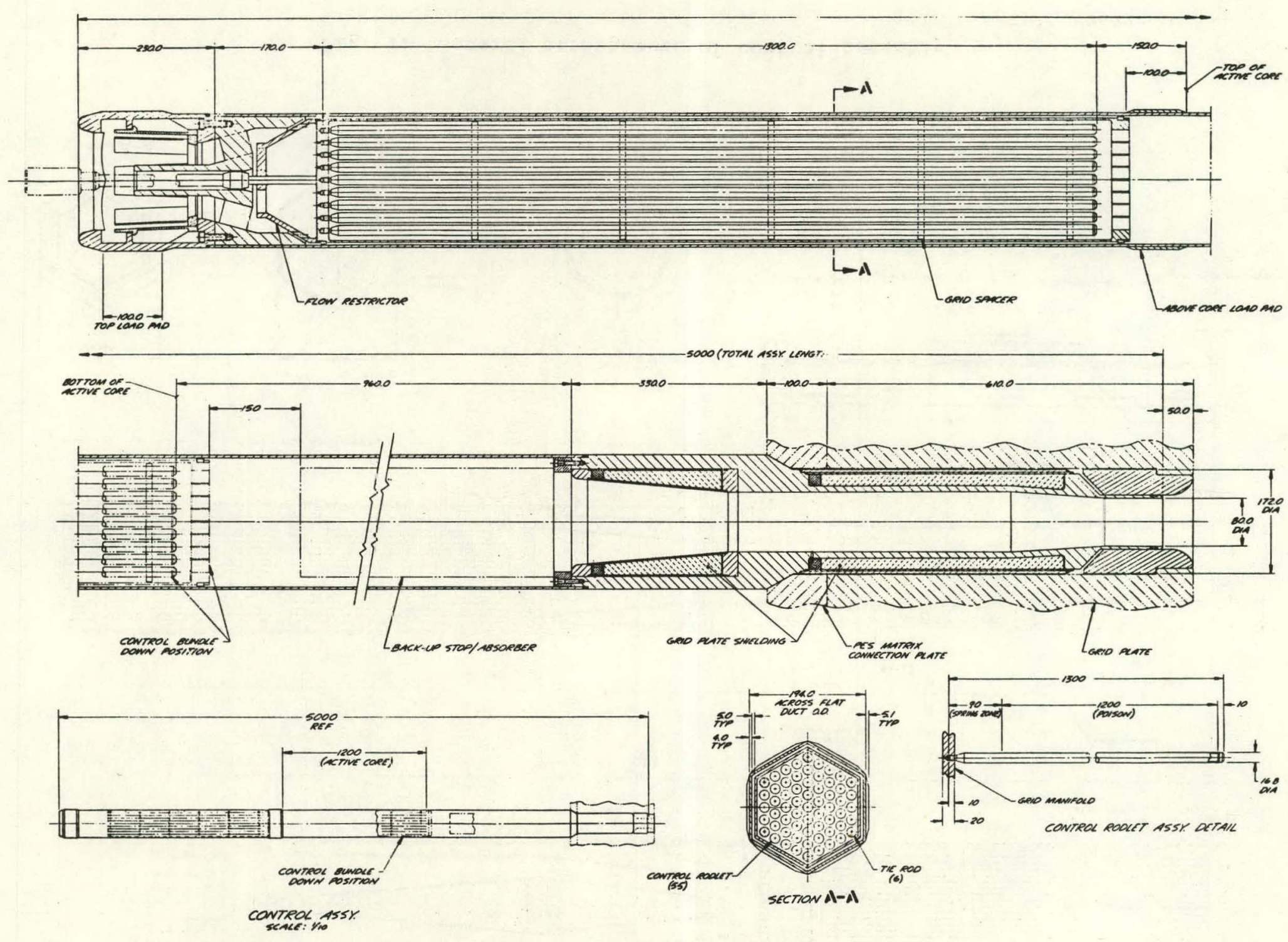

Fig. 3. General arrangement of fuel assembly 

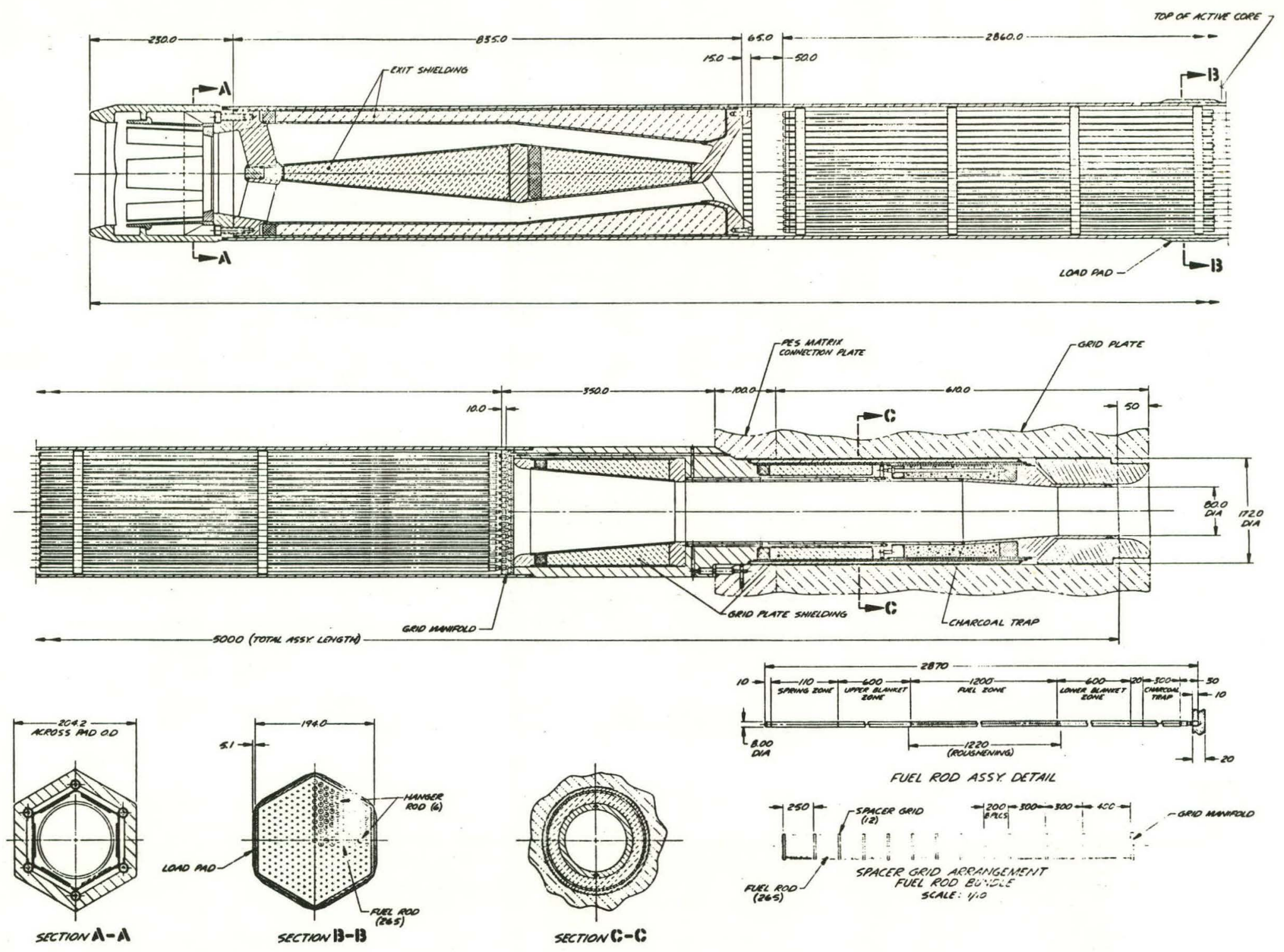

Fig. 9. General arrangement of control assembly 

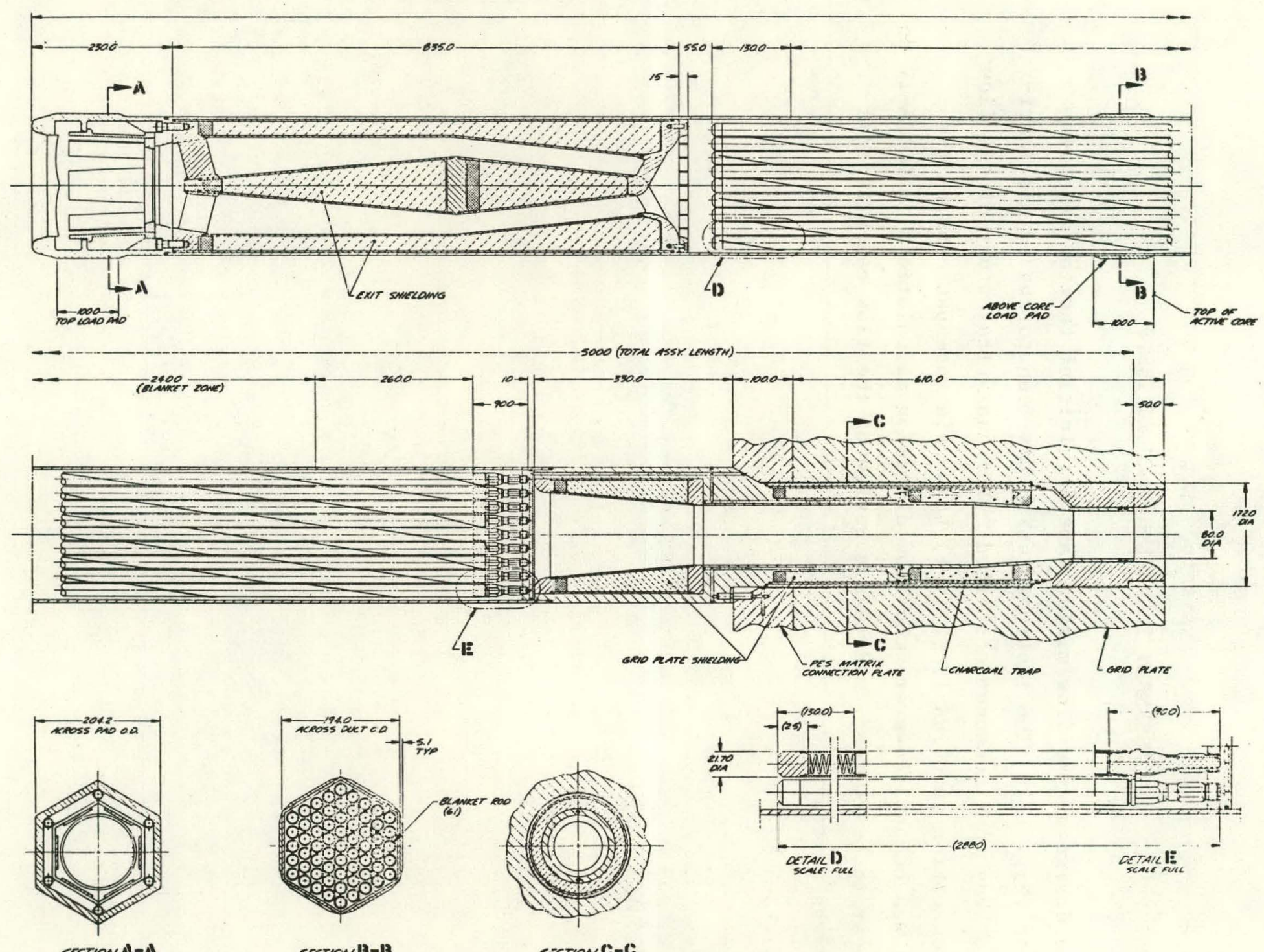

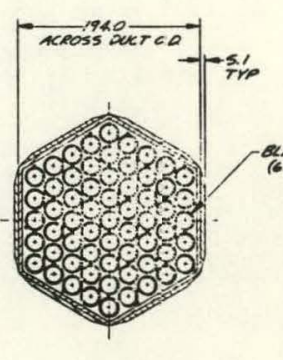

SECTION13-13

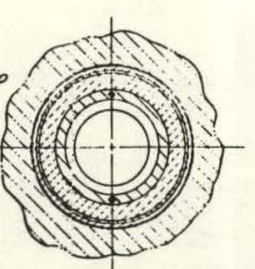

SECTION C:-C:

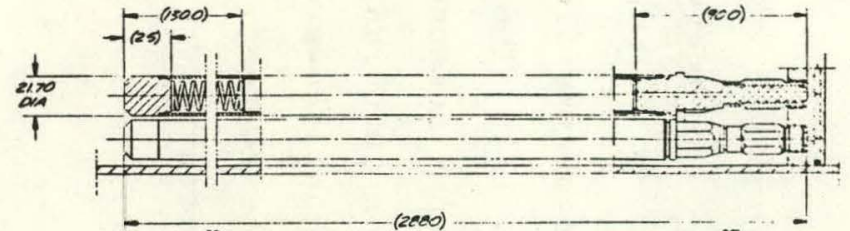

astale ()

CETAILIE
scule NuL

Fig. 10. Genera1 arrangement of blanket assembly 


\section{ASSEMBLY THERMAL-HYDRAULIC TESTS}

The design of the flow mixing vane for initial testing has been completed (Fig. 11). The instrumentation has been purchased and fabrication of key test components started. The analytical study of the flow diversion option in COBRA-IV (Ref. 1) to obtain vane patterns on the spacers was begun. However, the flow diversion calculations in COBRA-IV do not appear to be correct, and thus a review of the flow calculational methods was initiated. 


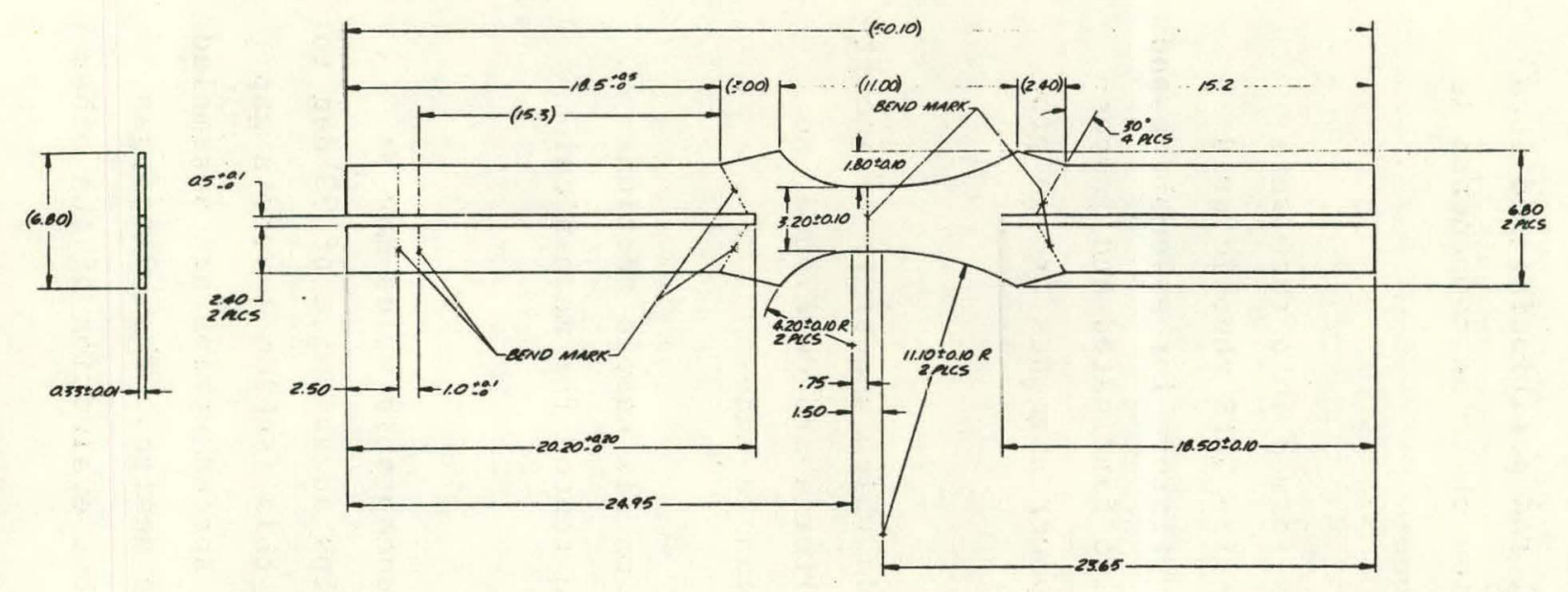

$\stackrel{N}{\omega}$
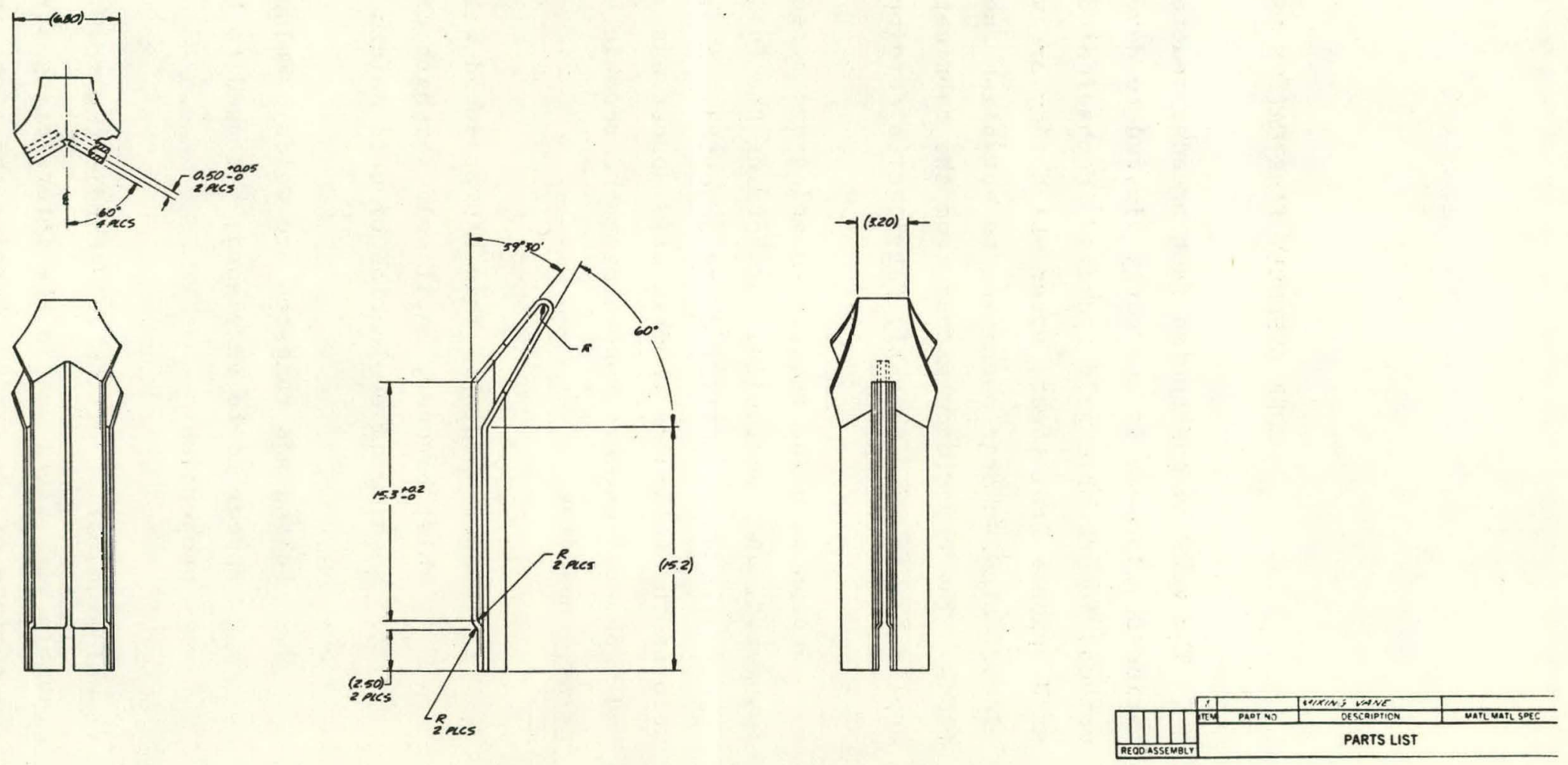

Fig. 11. Mixing vane 


\section{CORE ASSEMBLY FABRICATION DEVELOPMENT}

The work on gas-cooled fast breeder reactor (GCFR) core assembly fabrication development is currently limited to development of fabrication methods for rhombic grid spacers. Mechanical dies are used to form the grid spacers from sheet, after which they are welded together and sized by electrical discharge machining to establish fuel rod positioning pad locations. The experience gained from the fabrication of these components is applicable to core assembly fabrication development.

Strips with the required dimples and bosses formed into them were inspected, and the tooling for forming the full-size GCFR rhombic grid spacer straps was qualified and accepted. A jig/fixture for assembling and welding the full-size rhombic grid spacer was also fabricated and inspected. Several methods for welding the rhombic spacer segments are in progress, including

1. Laser-welding. This has produced welds which appear to be acceptable; however, until weld strength criteria are developed, no meaningful evaluation of weld joints can be made.

2. Pulsed gas tungsten arc welds. Welds on six sample sections appear to be very good, but need to be tested for mechanical properties.

Visual examination of the welds indicates that acceptable welds may be possible with slots cut in the intersecting strips at an angle of 90 deg to the surface of the strip. Cutting the slots in this fashion leaves a gap on opposite sides of each intersection when the spacer strips are assembled at the 60-deg intersection angle required by the design. The pulsed gas tungsten arc weld may result in the best weld, but evaluation of the other candidate methods will continue. 
Experience with fabrication of full-size GCFR core assembly components for steel melting and relocation tests (SMART) at Los Alamos Scientific Laboratory (LASL) is expected to be of value for achieving GCFR core assembly fabrication development objectives. During this quarter, five fullsize grid spacers (Fig. 12) fabricated by wire electrical discharge machining and two full-size mandrel drawn ducts (Fig. 13) were inspected and shipped to LASL. Other items were previously shipped: 460 cladding tubes for the heater rods which simulate the fuel rods; tubing for 33 sets of spacer grid support hanger rods, 4 formed duct halves; and 8 pieces of 4-mmthick, 764 × $3050 \mathrm{~mm} 316$ stainless steel sheet for guard heater shrouds.

The tubing (8.00-mm o.d. and 3065-mm length) for the fuel rod simulators for the core flow test loop (CFTL) has been fabricated, and the tooling for rib grinding has been qualified. Ribs have been ground over a $1220-\mathrm{mm}$ length on 10 tubes. The rib height and width and the top of rib and root radii were satisfactory for 9 of the 10 tubes.

Twenty-two hex-type grid spacers are being fabricated by wire electrodischarge machining of $20 \%$ cold-worked 316 stainless steel plate. The grid spacers will be used in assembly heat transfer and flow tests. Trial fabrication of one of the spacers by conventional numerically controlled machining has also been initiated. 


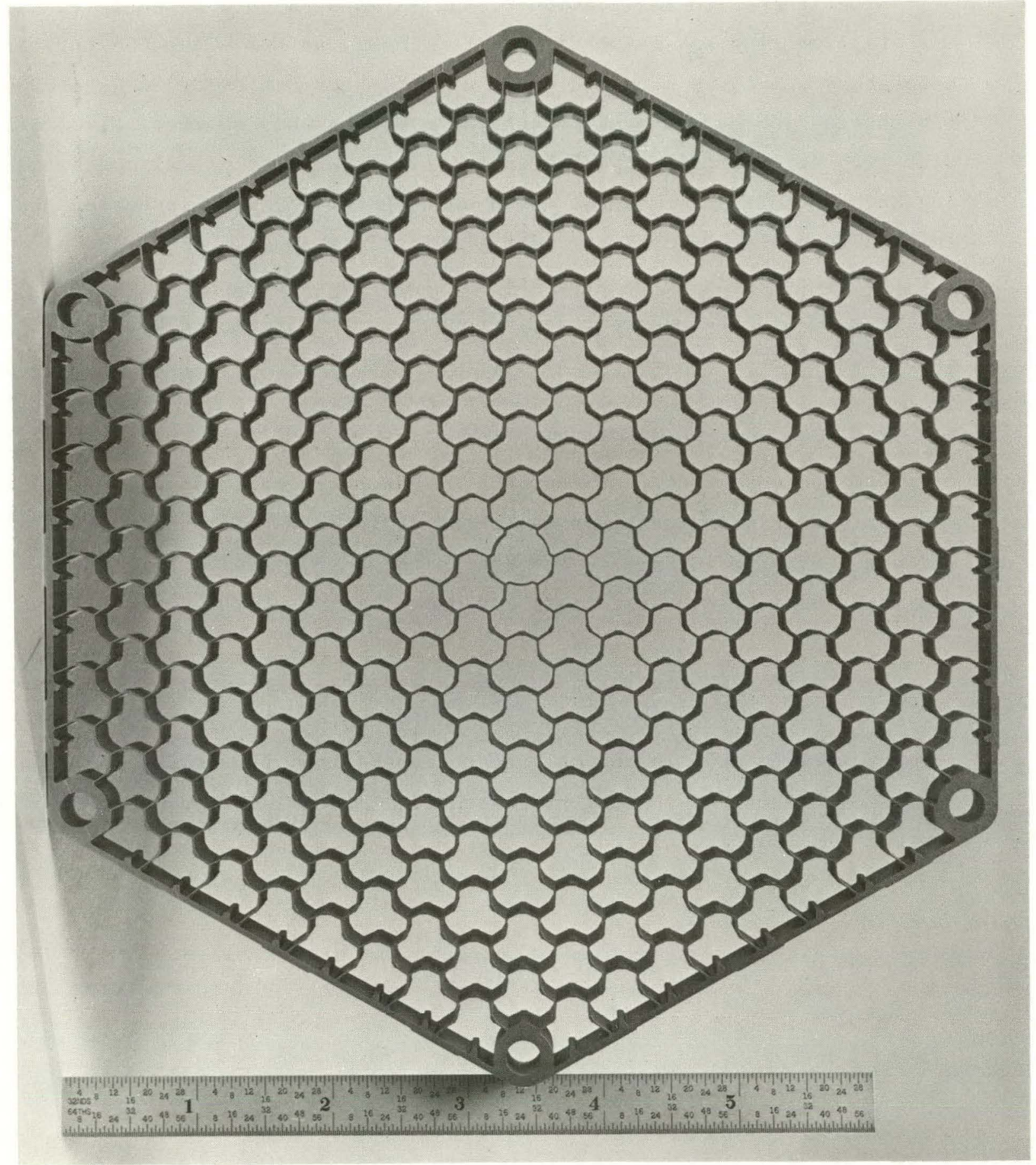

Fig. 12. One of five SMART grid spacers fabricated from 316 stainless steel plate by wire electrical discharge machining 


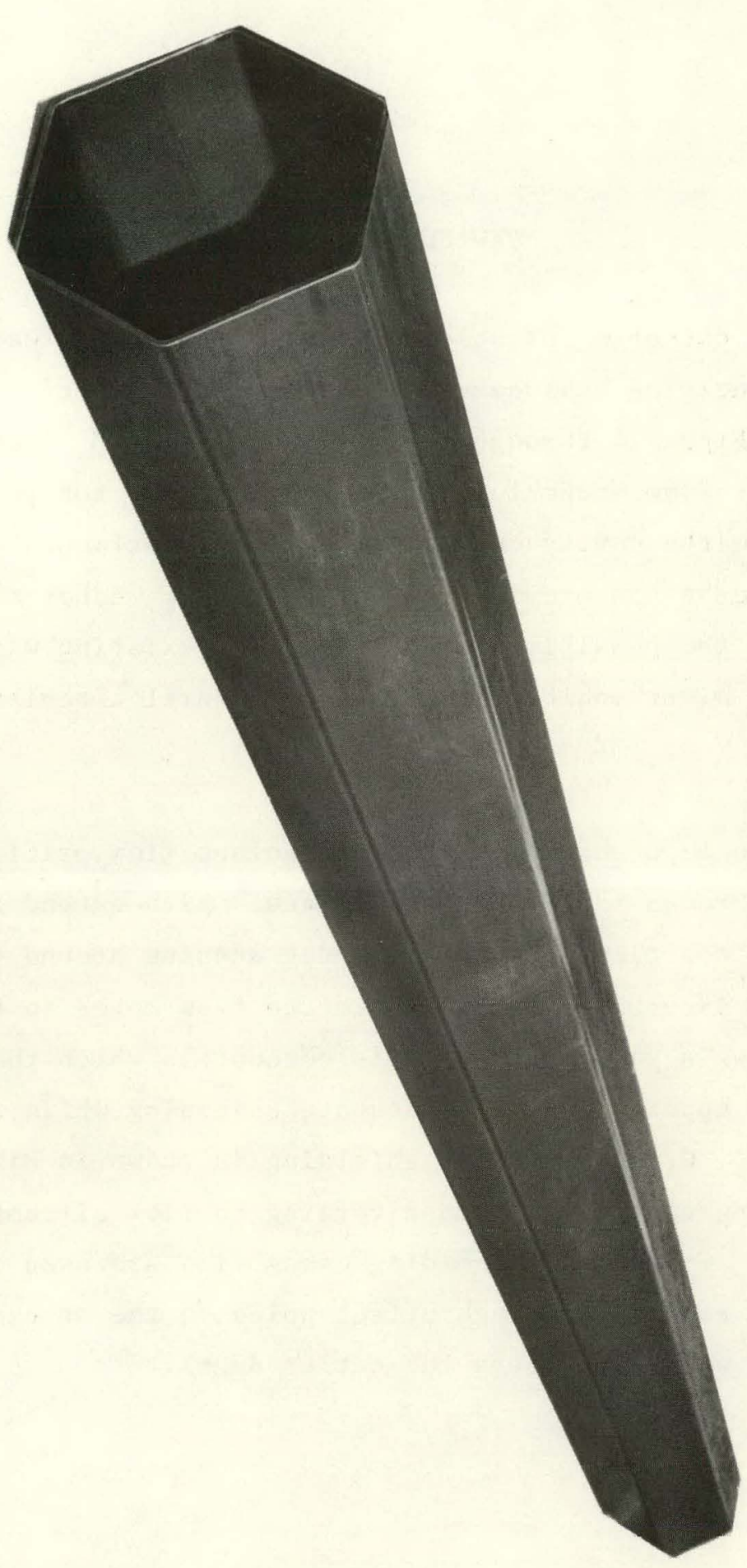

Fig. 13. One of two mandrel drawn ducts of $20 \%$ cold-worked stainless steel for SMART 
Four new concepts for shielding which recognize the fundamental design principle underlying enhancement of the probability of startup of natural circulation (Figs. 14 through 17) were developed. That is, all in-corecavity coolant flow directional changes necessary for preventing neutron streaming from the cavity must be made in the horizontal rather than the vertical plane as has previously been the case. Adherence to this principle minimizes the possibility of "cold" legs existing within the core cavity, which might inhibit the start of natural circulation (Figs. 14 through 17).

In the concept shown in Fig. 13, coolant flow exiting the core passes hoizontally through the Z-shaped passages, which extend for the entire height of the top plenum, into a 360-deg annulus around the periphery of the shielding assemblies. From there the flow moves to the outlet ducts. Figure 14 shows a refinement of this concept in which the slots are chevron shaped. This appears to offer adequate shielding while reducing coolant pressure drop. Crescent-shaped shielding is shown in Fig. 15, with all coolant exiting on one side and diverging to flow circumferentially to the outlet ducts. Concentric shielding assemblies are used in Fig. 16. The coolant flows radially through offset holes in the shielding to the outer annulus, from where it enters the outlet ducts. 


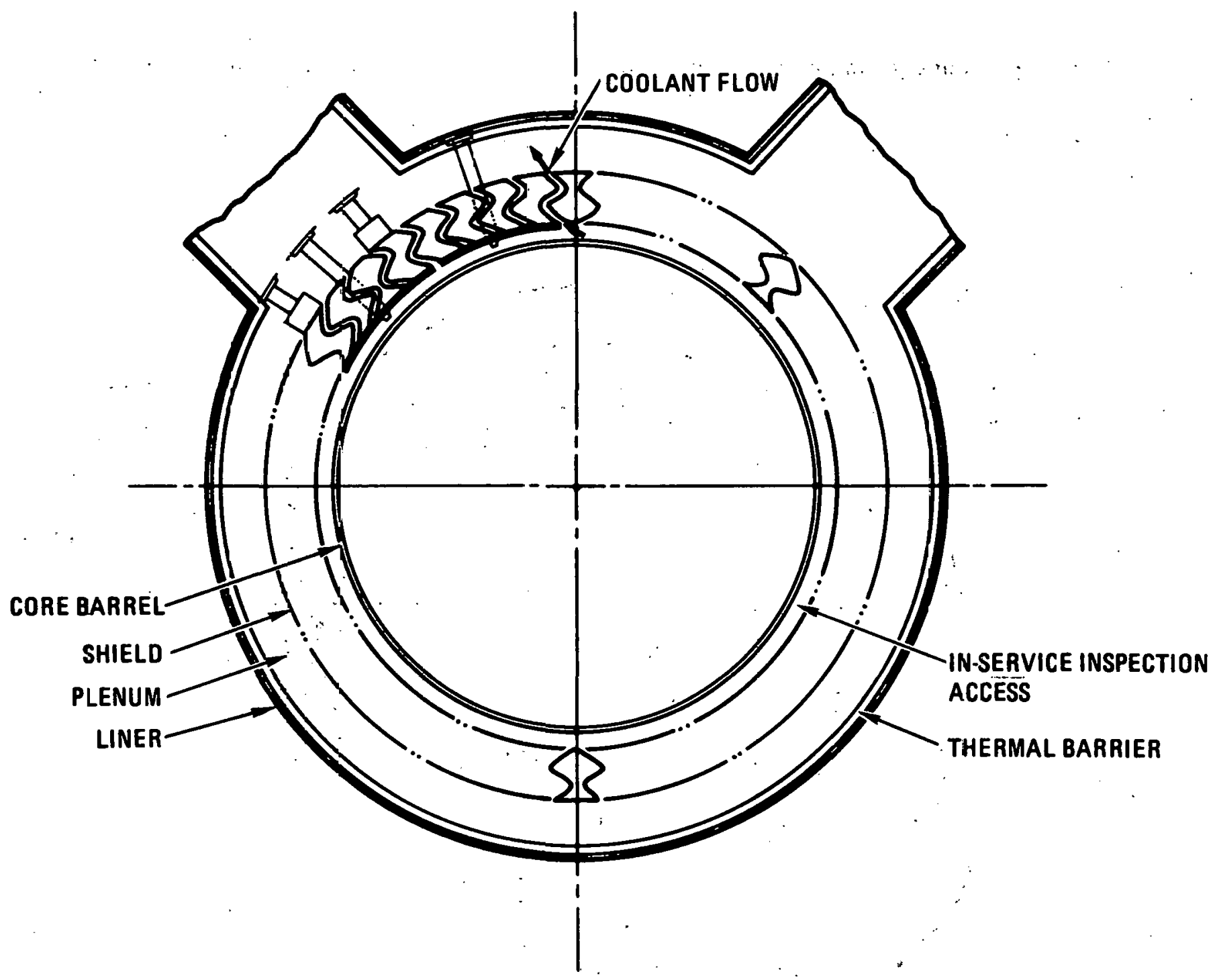

Fig. 14. Plan view of herringbone concept for upper and lower plenum shielding 


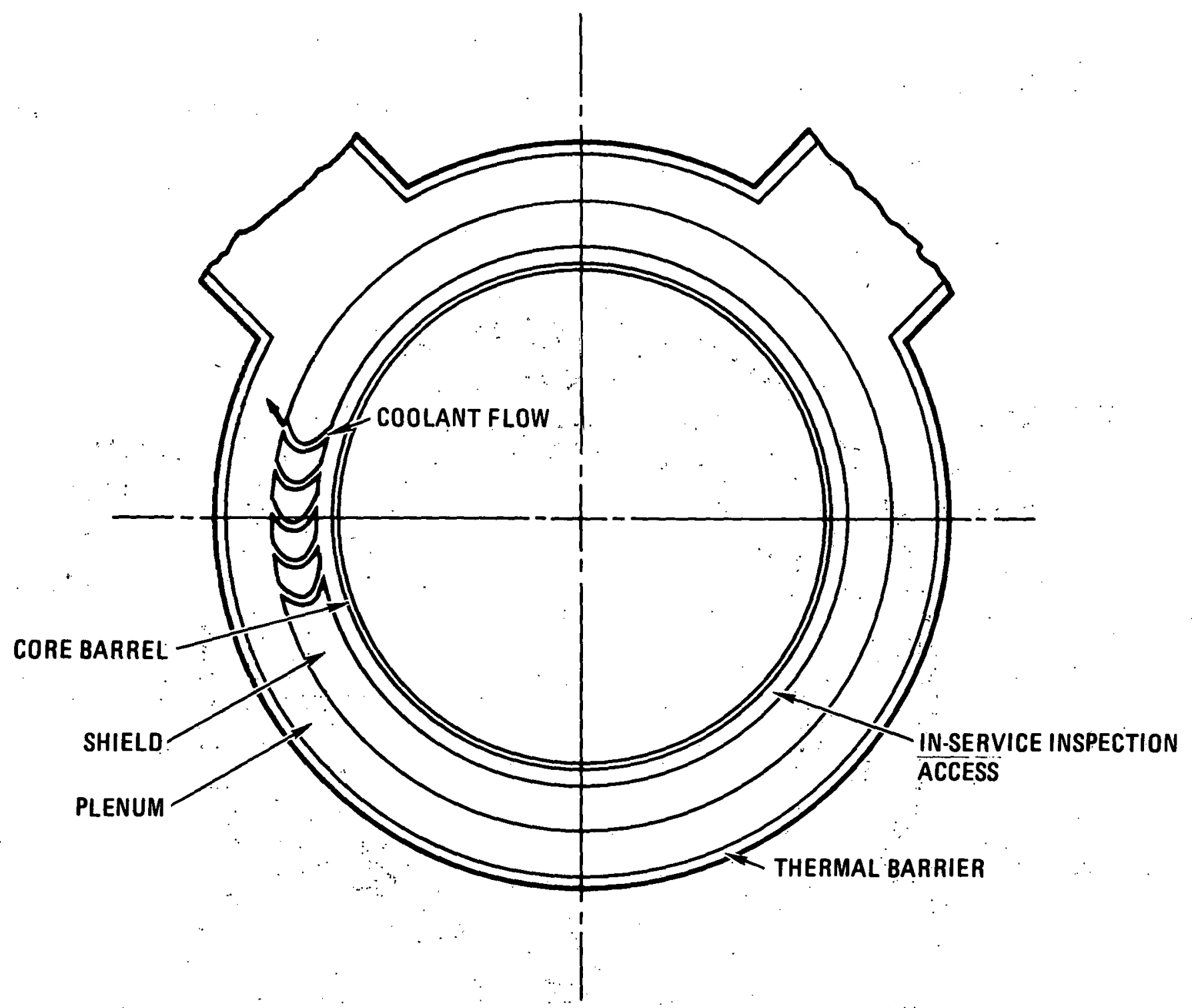

Fig. 15. Plan view of chevron concept for upper and lower plenum shielding 


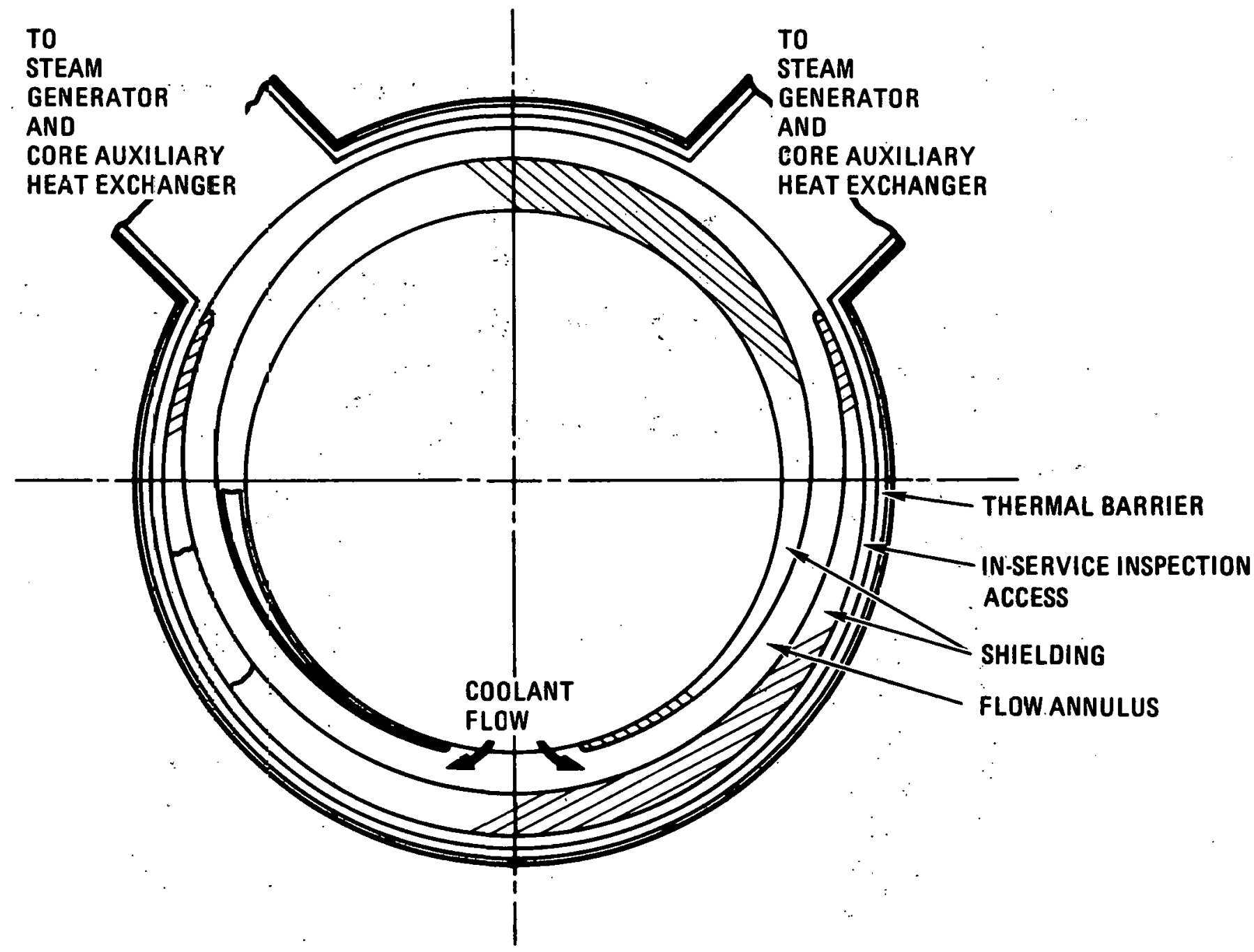

Fig. 16. Plan view of crescent concept for upper and lower plenum shielding 


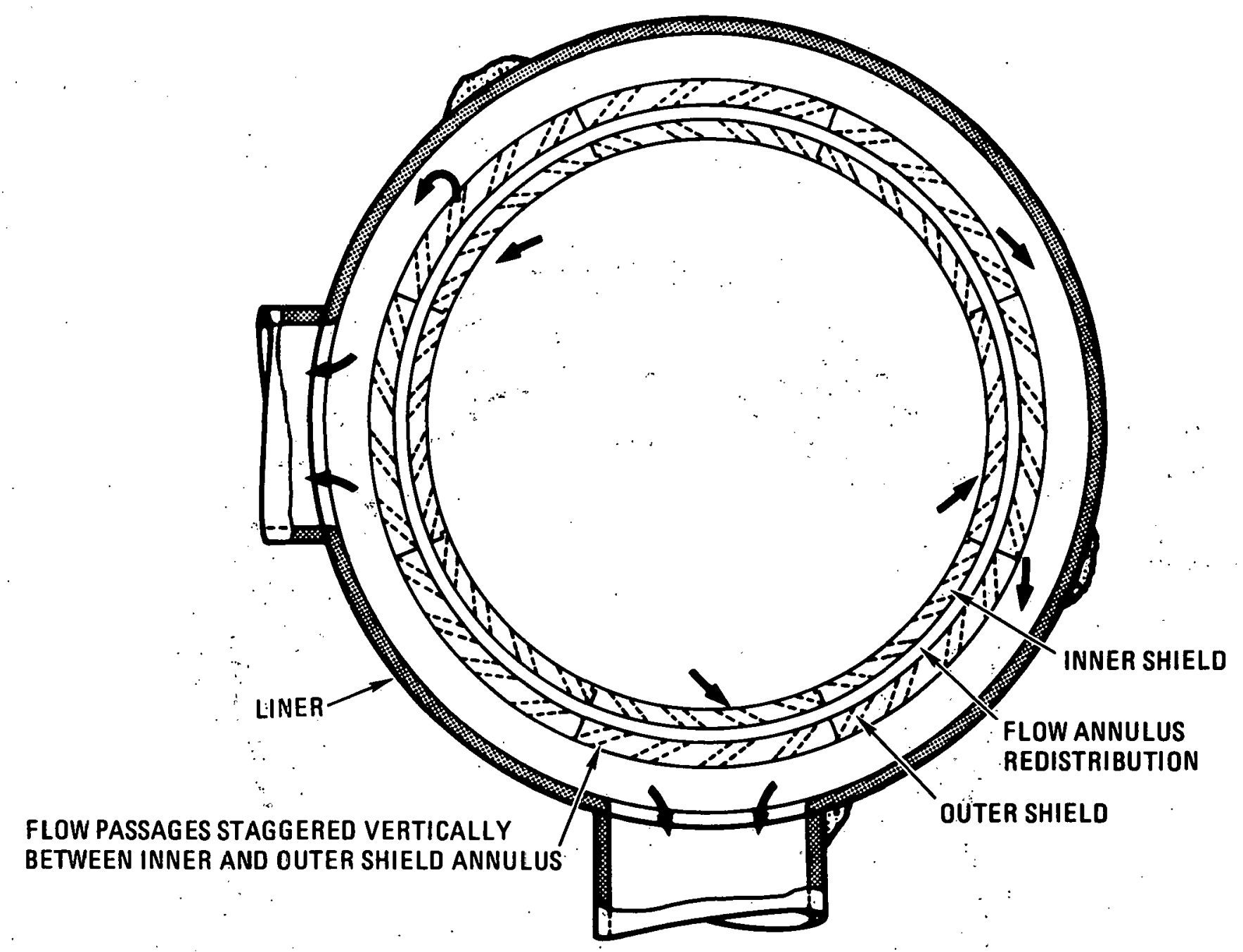

Fig. 17. Plan view of offset hole concept for upper and lower plenum shielding 


\section{SHIELDING PHYSICS DESIGN AND ANALYSIS}

The major shielding effort during this quarter was on the design and preliminary analysis of new upper and lower plenum shielding configurations. A new GCFR safety requirement calls for natural circulation through the core auxiliary heat exchanger (CAHE) flow circuit to be initiated in case of loss of reactor power (Refs. 2, 3). The guidelines for natural circulation given in Ref. 1 require that the shielding in the upper and lower plenums be designed as follows:

1. The shielding in the upper plenum should permit placement of the outlet ducts at the maximum height.

2. The shielding in the lower plenum should permit placement of the inlet ducts as close as possible to the lower level of the grid plate.

3. Any reversals of coolant flow in the vertical direction must be avoided.

Guideline 3 eliminates the reference upper and lower plenum shielding designs.

Several upper and lower plenum shield configurations were proposed and evaluated on the basis of (1) shielding effectiveness, (2) pressure drop, (3) ease of construction, and (4) scaling to a commerical GCFR. Figures 18 through 23 show the radial shield and the two basic types of upper and lower plenum shield configurations considered for further study in the twoloop demonstration plant. Figure 18 presents the radial shield in relation to the core barrel and grid plate. Figures 19 through 23 show the two candidate upper and lower plenum configurations. Figures 19 and 20 present 


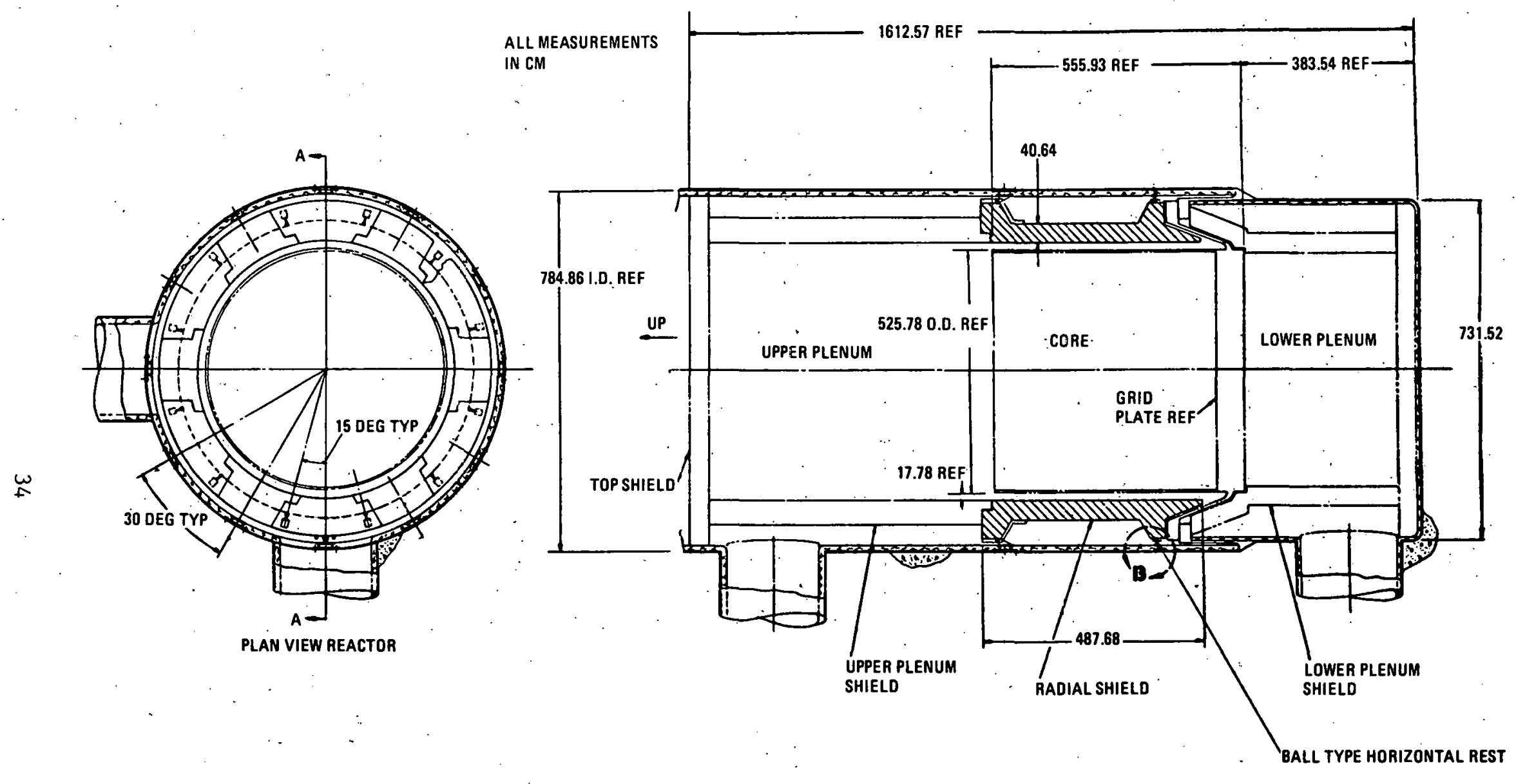

SEC A-A

Fig. 18. Plan view and vertical section of core and radial shielding for two-loop upflow GCFR 


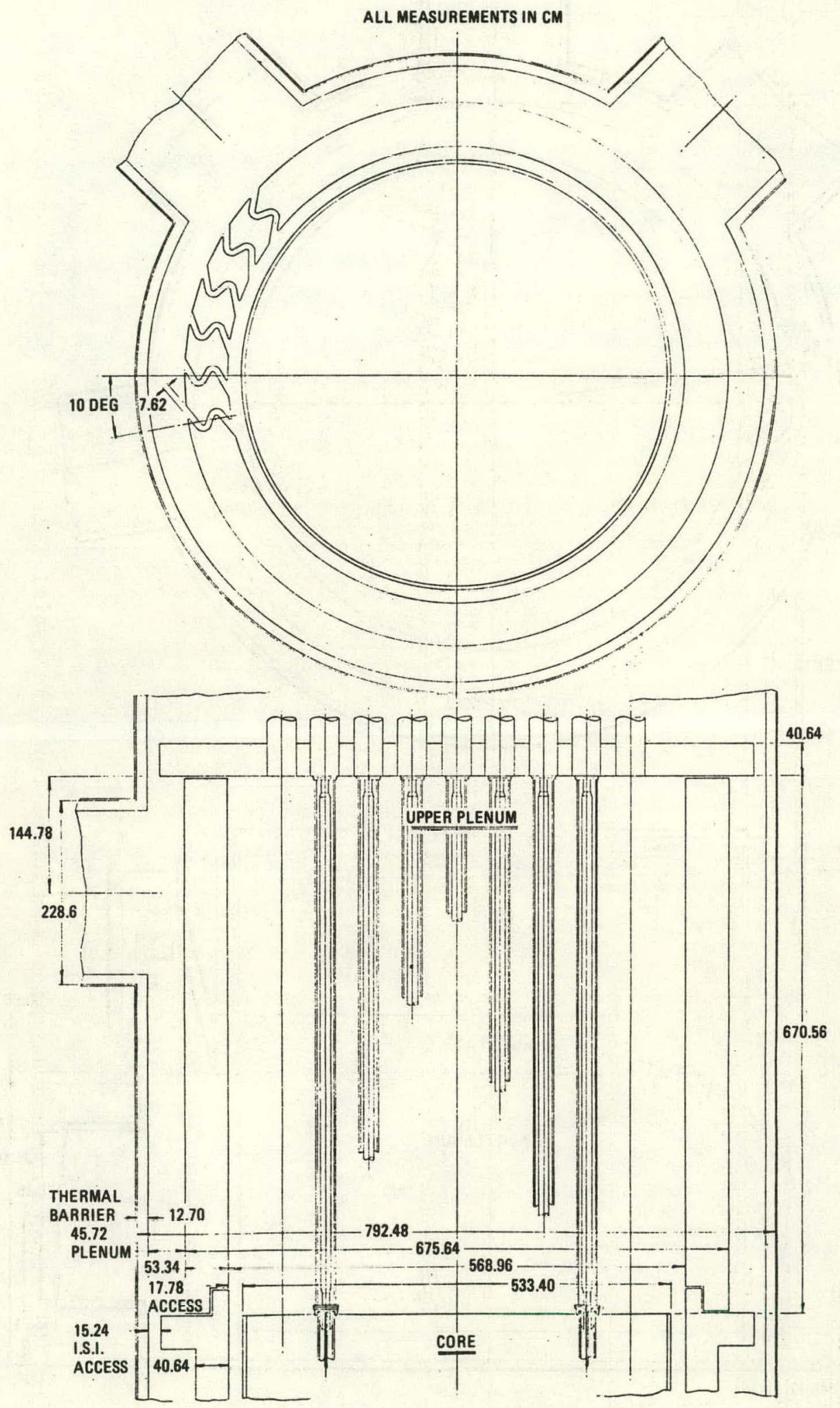

Fig. 19. Proposed upper plenum shielding with flow through vertical section for upflow GCFR 


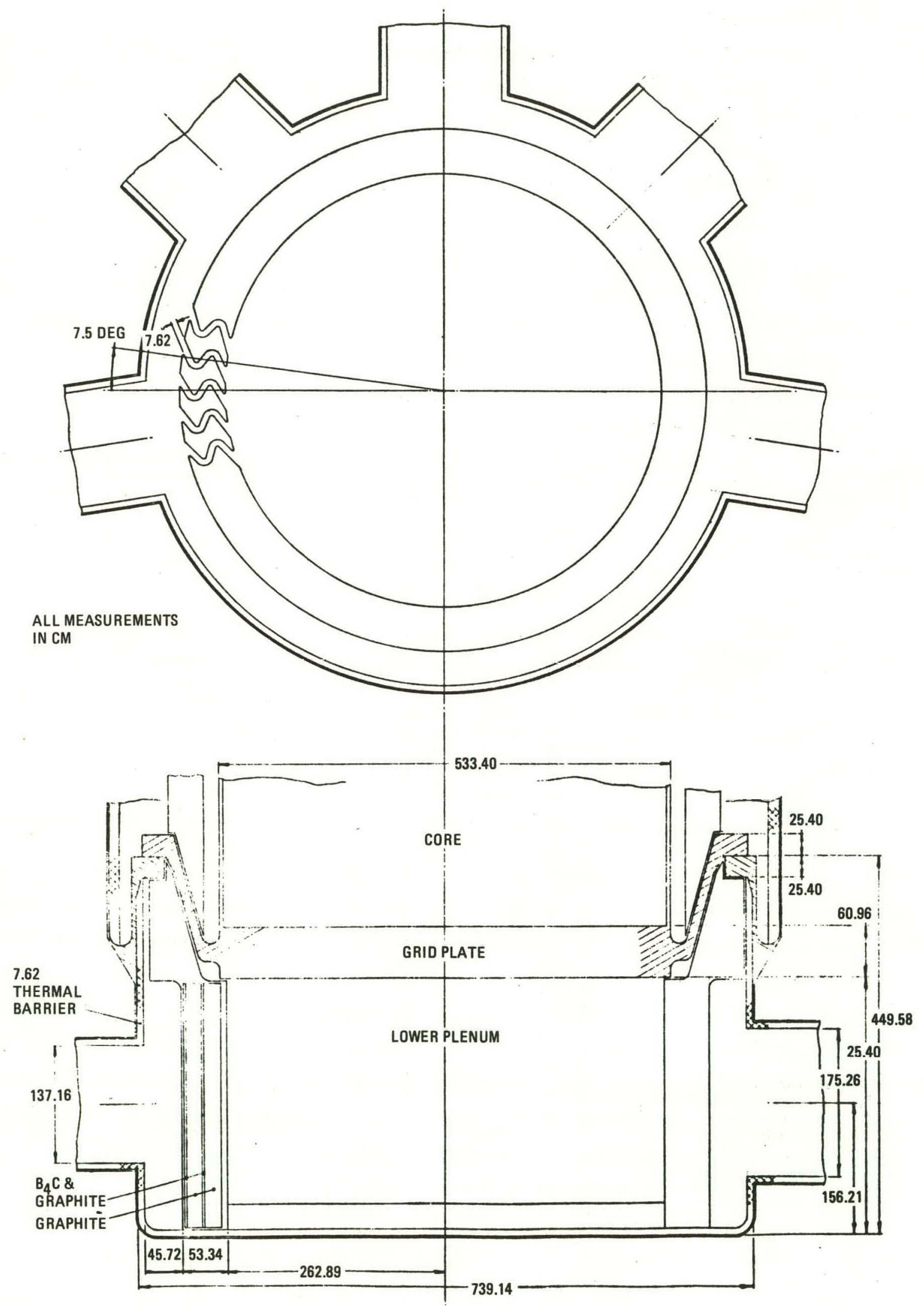

Fig. 20. Proposed lower plenum shielding with flow through vertical section for two-loop upflow GCFR 


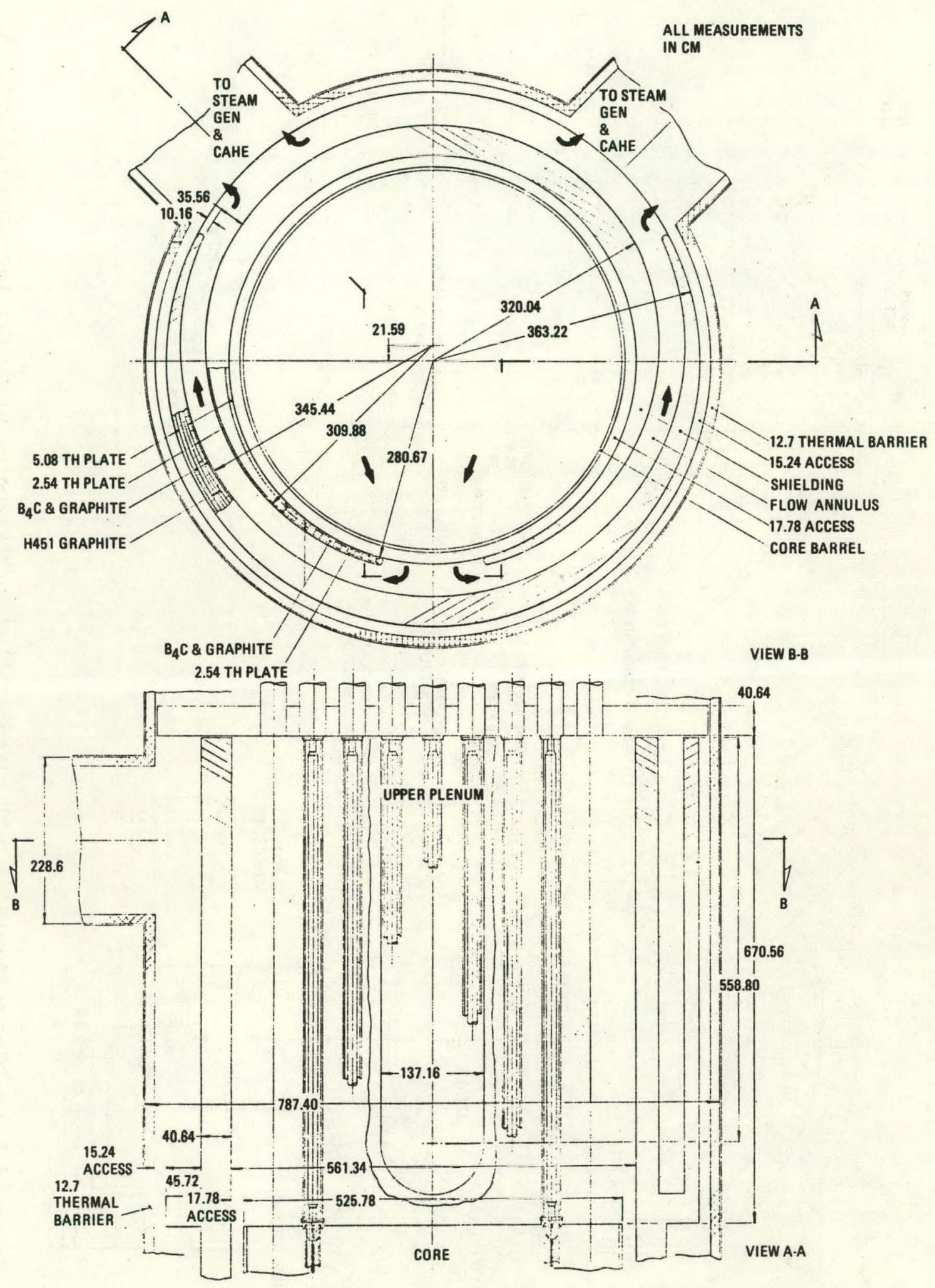

Fig. 21. Proposed upper plenum shielding with circular flow in horizontal plane for two-loop upflow GCFR 


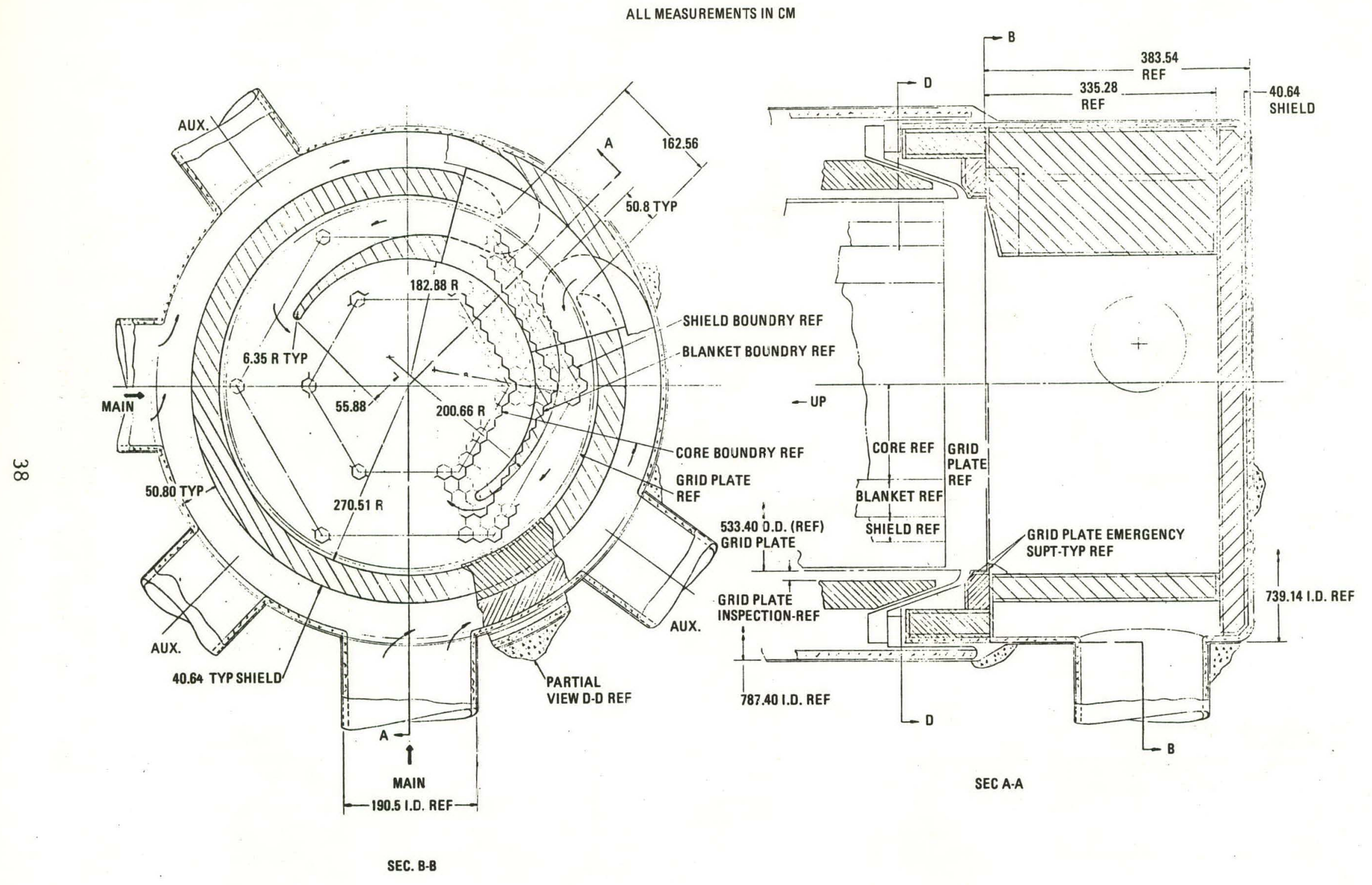

Fig. 22. Proposed lower plenum shielding with circular flow in horizontal plane for two-loop upflow GCFR 


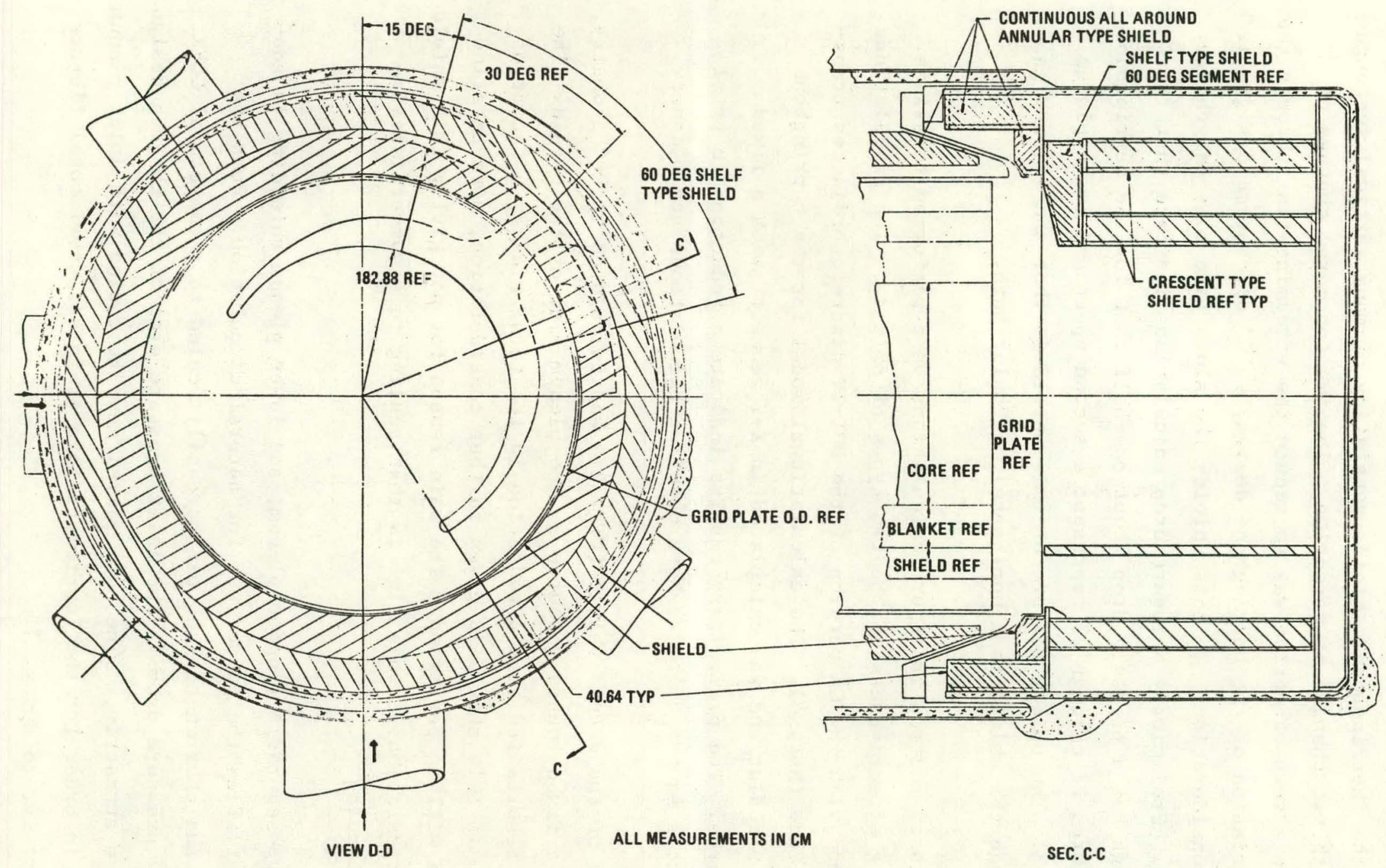

Fig. 23. Proposed lower plenum shielding with circular flow for two-loop upflow GCFR (section above level of grid plate) 
one design, the "herringbone" shield, consisting of many vertical rectangular slots with two changes of direction. The two (or more) changes of direction are a very effective way to reduce the streaming flux through the slots. A variation of the herringbone design, a "C" or chevron design, is also under consideration. In this shield, the slots have only one change in direction. Preliminary pressure drop calculations indicate that the chevron design has a pressure drop about one-half that for the herringbone design. Figures 21 through 23 represent a second upper and lower plenum configuration. The unique feature of this shield is that the coolant gas passes through the shield in a horizontal, circular path.

Preliminary neutron transport calculations were performed to assess the shielding effectiveness of the two types of shields. The calculations were performed with the GA version of the DOT-IV discrete ordinates transport theory code (Ref. 4). The calculational model for the herringbone design used one slot and was calculated in $\mathrm{X}-\mathrm{Y}$ geometry with a fixed boundary source. The preliminary results indicate a reduction in total flux of about a factor of 500. More detailed calculations are planned.

A model of the second shield (Fig. 21) was calculated in R- $\theta$ geometry, again using a fixed boundary source on the plenum side of the shield. The preliminary results indicate a reduction in the total flux by a factor of about 1200. If this shield is given further consideration, more detailed calculations will be performed. The main reason for not giving this shield further consideration at this time is that scaling to a commercial-size GCFR is difficult.

The proposed radial, upper plenum, and lower plenum shielding is adequate and satisfies the guidelines for natural circulation. Both the herringbone and chevron designs can be easily scaled to a commercial GCFR and have low pressure drops. The lower pressure drop of the chevron design makes it more attractive. The core barrel must be cooled with inlet plenum coolant gas in order for the low-temperature stainless steel total fluence limit of $10^{22}$ nvt to apply. 
REFERENCES

1. Wheeler, C. L., et al., "COBRA-IV-I: An Interim Version of COBRA for Thermal-Hydraulic Analysis of Rod Bundle Nuclear Fuel Elements and Cores," Battelle Northwest Laboratory Report BNWL-1962, March 1976.

2. Parme, L. L., General Atomic unpublished data, May 15, 1979.

3. Parme, L. L., and W. A. Medwid, "Natural Circulation in the Upflow GCFR," General Atomic unpublished data, June 1979.

4. Rhoades, W. A., et al., "The DOT-IV Two-Dimensional Discrete-Ordinates Transport Code With Space-Dependent Mesh and Quadrature," Oak Ridge National Laboratory Report ORNL/TM-6529, 1978. 